\title{
Therapeutic Implications for PDE2 and cGMP/cAMP Mediated Crosstalk in Cardiovascular Diseases
}

\author{
Mirna S. Sadek, Eleder Cachorro, Ali El-Armouche * and Susanne Kämmerer * \\ Department of Pharmacology and Toxicology, Carl Gustav Carus Faculty of Medicine, Technische Universität \\ Dresden, Fetscherstraße 74, 01307 Dresden, Germany; mirna.sadek@tu-dresden.de (M.S.S.); \\ eleder.cachorro_puente@tu-dresden.de (E.C.) \\ * Correspondence: ali.el-armouche@tu-dresden.de (A.E.-A.); susanne.kaemmerer@tu-dresden.de (S.K.); \\ Tel.: +49-(0)-351-458-6279 (A.E.-A.); +49-(0)-351-458-6300 (S.K.)
}

Received: 2 September 2020; Accepted: 8 October 2020; Published: 10 October 2020

\begin{abstract}
Phosphodiesterases (PDEs) are the principal superfamily of enzymes responsible for degrading the secondary messengers $3^{\prime}, 5^{\prime}$-cyclic nucleotides cAMP and cGMP. Their refined subcellular localization and substrate specificity contribute to finely regulate cAMP/cGMP gradients in various cellular microdomains. Redistribution of multiple signal compartmentalization components is often perceived under pathological conditions. Thereby PDEs have long been pursued as therapeutic targets in diverse disease conditions including neurological, metabolic, cancer and autoimmune disorders in addition to numerous cardiovascular diseases (CVDs). PDE2 is a unique member of the broad family of PDEs. In addition to its capability to hydrolyze both cAMP and cGMP, PDE2 is the sole isoform that may be allosterically activated by cGMP increasing its cAMP hydrolyzing activity. Within the cardiovascular system, PDE2 serves as an integral regulator for the crosstalk between cAMP/cGMP pathways and thereby may couple chronically adverse augmented cAMP signaling with cardioprotective CGMP signaling. This review provides a comprehensive overview of PDE2 regulatory functions in multiple cellular components within the cardiovascular system and also within various subcellular microdomains. Implications for PDE2- mediated crosstalk mechanisms in diverse cardiovascular pathologies are discussed highlighting the prospective use of PDE2 as a potential therapeutic target in cardiovascular disorders.
\end{abstract}

Keywords: PDE2; cAMP/cGMP crosstalk; natriuretic peptides; NO signaling; heart failure; arrhythmia; inflammation; cardiovascular disease

\section{Introduction}

Cardiovascular diseases (CVDs) remain a leading cause of morbidity and mortality and impose a major global health care burden. In 2017, 17.8 million deaths due to CVDs were estimated worldwide and projections anticipate a 30\% increase in CVD prevalence from 2015 to 2035 [1-3]. Atherosclerotic and ischemic cardiac conditions contribute to CVD progression leading to the development of coronary artery disease and peripheral vascular disease. Subsequently, these conditions increase the susceptibility towards myocardial infarction (MI), cardiac arrhythmias and strokes [4]. Etiological predisposing risk factors include hypertension, hyperlipidemia, obesity, diabetes, lack of physical activity and smoking. Currently available therapeutic strategies thereby aim to prevent and limit predisposing causes. In addition to lifestyle modifications, antihypertensive, anticoagulatory and lipid lowering drugs as well as $\beta$-blockers and inhibitors of the renin-angiotensin-aldosterone system are principal pharmacotherapeutic agents commonly used in CVD patients [4,5]. Despite the effectiveness of the aforementioned medicaments, poor patient prognosis and inadequate improvement are achieved.

Present therapeutic approaches considerably neglect and overlook signalling processes occurring at the subcellular level in various cardiovascular tissues. However, increasing evidence currently points 
towards perturbed functional alterations in multiple cardiac subcellular microdomains [6]. Pathological redistribution of compartmentalized cellular components modulating cyclic nucleotide secondary messenger signalling are increasingly being reported to prompt pathways associated with adverse cardiac remodeling [7-9]. Many researchers have therefore focused to investigate compartmentalized microdomain signalling and established multiple indispensable novel technology platforms to examine complex signalling microcompartments [10-12]. Development of cardiac and vascular microdomain specific therapeutics may potentially offer a breakthrough in CVD therapy by limiting pathological signalling and remodeling mechanisms.

Cyclic nucleotide degrading phosphodiesterases (PDEs) are a superfamily of hydrolyzing enzymes that play an important role in the regulation of dynamic cyclic nucleotide microdomains [13]. Myocardial predominant PDE3 and PDE4 have been more comprehensively studied. Inhibitors for these PDEs, as well as for PDE5, have been recently investigated for use in multiple clinical trials $[14,15]$. Currently, there is increasing interest to inspect the role of PDE2 in the cardiovascular system. Several studies demonstrated the impact of PDE2 on heart rate regulation and modulation of cardiac function and remodeling mechanisms under pathological conditions [16-19]. In this review, we thereby aim to provide a comprehensive overview regarding compartmentalization mechanisms within the cardiovascular system and describe the role of PDE2 in various myocardial cellular microdomains. A synopsis of PDE2 crosstalk mechanisms identified in various cardiovascular disease settings is also discussed highlighting potential implications for the use of PDE2 as a therapeutic target.

\section{Cyclic Nucleotide Signalling and Compartmentalization}

The intracellular secondary messengers $3^{\prime}, 5^{\prime}$-cyclic adenosine monophosphate (cAMP) and $3^{\prime}, 5^{\prime}$-cyclic guanosine monophosphate (cGMP) play a central role in the cardiac and vascular signalosome, regulating multiple cellular processes under physiological as well as pathological conditions. Synthesis and distribution of both cAMP and cGMP is highly regulated by multiple complex mechanisms at a subcellular level and also diversely in different regions of the heart $[6,20]$.

\section{1. cAMP Signalling Pathway}

Activation of G protein coupled receptors (GPCRs) by various neurotransmitters and hormones acts to modulate cAMP synthesis. Activators binding to their corresponding GPCR include: epinephrine and noradrenaline which bind to $\beta$-adrenoceptors ( $\beta$-ARs) [21]; prostaglandin E1 and E2 bind to EP receptors [22,23]; glucagon binds to the glucagon receptor [24] and glucagon-like peptide-1 also activates GLP1-receptors [25]. Upon binding, $\mathrm{G} \alpha_{\mathrm{s}}$-GPCR conformational changes trigger the activation of diverse adenylyl cyclase (AC) isoforms, converting ATP to cAMP [26-28]. On the other hand, soluble adenylyl cyclases (sACs) are activated by bicarbonate, enhancing the production of cAMP in the cytosol and mitochondria [29]. In general, nine AC isoforms (AC1-9) have been characterized in the human heart, with AC5 and AC6 being the most prominent in cardiomyocytes [30-32]. In the myocardium, sympathetic $\beta$-adrenergic signalling is the principle regulatory pathway modulating the cardiac activity upon elevating cAMP levels. cAMP-dependent activation of downstream targets increases the cardiac heart rate (chronotropic effects), contractility (ionotropic effects) and relaxation time (lusitropic effects) [33,34]. Diversely, cAMP coordinates multiple fundamental vascular processes including vascular smooth muscle cell (VSMC) proliferation [35] and vasodilatation [36] and additionally regulates endothelial barrier function [37].

The major cAMP effector target is protein kinase A (PKA). cAMP-dependent activation of PKA leads to the phosphorylation of a plethora of proteins constituting the cardiac excitation-contraction coupling (ECC) machinery. In the heart, increased cardiac contractility and heart rate are achieved upon PKA-dependent phosphorylation of L-type $\mathrm{Ca}^{2+}$ channels (LTCC) at the plasmalemma and ryanodine receptors (RyRs) and phospholamban (PLB) at the sarcoplasmic reticulum (SR), enhancing $\mathrm{Ca}^{2+}$ fluxes and cytosolic $\mathrm{Ca}^{2+}$ levels [33]. At the myofilaments, phosphorylation of the myosin-binding protein $\mathrm{C}$ (MYBPC) increases the speed of cross-bridge formation and contractile kinetics [38]. Lusitropic 
effects are on the other hand achieved upon PKA phosphorylation of phospholamban and troponin I, which speed up SR Ca ${ }^{2+}$ re-uptake and dissociation of $\mathrm{Ca}^{2+}$ from the myofilaments, respectively [39]. To the contrary, sustained catecholaminergic $\beta$-AR stimulation promotes maladaptive cAMP/PKA signalling [40]. PKA-dependent phosphorylation of the cAMP response element binding protein (CREB) family induces transcription of hypertrophic factors and the inducible cAMP early repressor (ICER) prompting impaired mitochondrial function and apoptosis [41-43]. On the other hand, elevated cAMP levels and increased PKA activity promote endothelial barrier stability and vasodilatation [44]. In VSMCs, cAMP/PKA signalling enhances $\mathrm{SR} \mathrm{Ca}^{2+}$ re-uptake, increases the activity of various hyperpolarizing $\mathrm{K}^{+}$channels and may decrease $\mathrm{Ca}^{2+}$ sensitivity of the contractile machinery to promote vasodilatation [36].

Another important cAMP downstream target is the family of exchange proteins directly activated by cAMP (EPAC). Like PKA, EPAC enhances cardiac contractility upon activation of Rap-, PLC $\varepsilon^{-}$, protein kinase C (PKC)- and CaMKII-mediated signalling, which subsequently increase $\mathrm{Ca}^{2+}$ transients and phosphorylation of RyRs and PLB. Anomalous EPAC signalling is often implicated under pathological conditions and was shown to contribute to maladaptive hypertrophic remodeling processes, fibrosis, arrhythmia and heart failure [45]. Similarly, cAMP/EPAC signalling regulates VSMC proliferation and migration and also mediates vasorelaxation upon modulation of $\mathrm{K}^{+}$channel and RhoA activity [44]. In vascular endothelial cells (VECs), EPAC plays a crucial role to mediate cAMP-induced endothelial barrier strengthening. EPAC promotes tightened cadherin cell-cell junctions and prevents cadherin redistribution. Additionally, EPAC negatively regulates the pro-inflammatory JAK/STAT cascade to abrogate inflammation [44].

Furthermore, cAMP directly promotes chronotropic effects upon activating cyclic nucleotide gated ion channels (CNGCs) such as HCN channels expressed in the sinus node. cAMP-induced increase in $\mathrm{HCN}$ channel generated $\mathrm{I}_{\mathrm{f}}$-currents enhances the sinus frequency to elicit spontaneous action potentials and hence the heart rate [46]. CNGCs are also expressed in VSMCs and VECs modulating the vascular tone $[47,48]$. Recently, the cAMP interacting Popeye-domain-containing proteins (POPDC) have been identified to play a critical regulatory role in cardiac pace maker cells at both the sinoatrial and atrioventricular nodes modulating cardiac conduction [49]. POPDC proteins are located in several membrane compartments interacting with TREK 1 channels, caveolin 3, dysferlin and dystrophin to maintain the cardiomyocyte structure and function [50,51].

\section{2. cGMP Signalling Pathway (NO, Natriuretic Peptides)}

In recent years, there has been increasing interest to investigate cardiac cGMP signalling potentiators due to their eminent cardioprotective role [52]. The second messenger cGMP is catalyzed from its precursor GTP by two distinct guanylate cyclase families, the soluble guanylyl cyclases (sGC) and particulate guanylyl cyclases (pGC) [53,54]. sGCs, also commonly known as NO-GCs, are activated by nitric oxide (NO) produced by NO synthases (NOS) in cardiac interstitial cells [55]. NO initiates the cGMP signalling cascade upon activation of cytosolic NO-GC1 predominantly, while NO-GC2 has been shown to play a more prominent role in other organs, e.g.- - the brain [56,57]. Diversely, membrane bound pGCs are stimulated via various natriuretic polypeptide (NP) hormones [58]. Atrial (ANP) and brain (BNP) NPs are released primarily from the atria and ventricles consequently upon neurohormonal or mechanical stimulation of the myocardium (stretching or elevated blood pressure). On the other hand, the C-type NP (CNP) is mainly derived from endothelial cells of the vasculature and fibroblasts. While ANP and BNP predominantly interact with the GC-A receptor (also known as NPR-1 or NPR-A) to promote CGMP synthesis, CNP exhibits a higher affinity towards the GC-B (NPR-2 or NPR-B) receptor [58-60]. Both sGC and pGC generate spatially distinct cGMP signals within cardiac myocytes [61].

Upon the activation of GCs, produced cGMP acts to mediate crucial regulatory responses upon interacting with its main effector kinase PKG (protein kinase G) [62,63]. In the heart, cGMP acts to modulate cardiac contractility and enhance relaxation kinetics via PKG-dependent 
phosphorylation of LTCC, titin, troponin I and phospholamban [64,65]. More importantly, cGMP-mediated PKG activity was also shown to inhibit maladaptive cardiac remodeling processes. For example, cGMP/PKG-dependent phosphorylation of LTCC and TRPC6 channels subsequently suppresses the $\mathrm{Ca}^{2+}$-dependent calcineurin-NFAT hypertrophic pathway [66,67]. Also, PKG-mediated phosphorylation of Regulator of G protein Signalling proteins (RGS2 and RGS4) increases their activity to inhibit sustained catecholaminergic-induced Gq signalling and hypertrophy $[68,69]$. The cGMP/PKG signalling cascade also contributes to protect against ischemic injury and cardiomyocyte death, minimizing the infarct size after myocardial ischemia-reperfusion injury in rodents and in humans [70,71]. PKG modulation of phospholemman protects against reperfusion injury via stimulation of the $\mathrm{Na}^{+} / \mathrm{K}^{+}$ATPase and thereby limits $\mathrm{Na}^{+}$accumulation during cardiac ischemia [72]. Other mechanisms have also been reported, including PKG-induced opening of mitoK ${ }_{\text {ATP }}$ channel and upregulation of the antiapoptotic Bcl-2, thus inhibiting mitochondrial permeability transition (MPT) pore formation and cell death [73-75]. Thereby, the cGMP signalling cascade additionally functions as a cardiac halting or brake system ensuring appropriate cardiac function and limits pathological signal transduction.

In contrast to the heart, cGMP does not act to antagonize cAMP-mediated responses in VSMCs, however both cyclic nucleotides induce similar physiological functions. cGMP/PKG signalling is the principal modulator of the vascular tone and acts to maintain vascular homeostasis as well as cell survival [76]. This is achieved downstream upon both sGC and pGC-induced cGMP/PKG activation. PKG-mediated phosphorylation of the myosin light chain phosphatases, RhoA, RGS-2, IRAG and calcium-sensitive potassium channels $\left(\mathrm{BK}_{\mathrm{Ca}}\right.$ ) promote vasodilation $[36,76]$.

Similar to cAMP, cGMP can partially activate CNGCs and thereby modulate beat frequency initiation in sinoatrial cells [62,77]. Moreover, cGMP is able to regulate the activity of multiple phosphodiesterase (PDE) enzymes expressed in the myocardium, providing a setting for crosstalk mechanisms between both cAMP/cGMP pathways as will be discussed in the following sections [62,78].

\subsection{Cellular Compartmentalization Mechanisms}

Despite the diverse given intracellular effects of cAMP and cGMP, distinct downstream responses are specifically provoked subsequently to various receptor stimuli. Already in 1979, contrasting physiological outcomes on cardiac contractility and intracellular signal transduction were described upon specific cardiac GPCR stimulation, although comparable cAMP levels were generated [79]. This has led to the current widely accepted model of compartmentalized cyclic nucleotide signalling. The model presumes that distinct responses are achieved upon the activation of specific signal transduction components coordinating cAMP/cGMP gradients including receptors, modulators and targets. Such components may be assembled in macromolecular complexes that are spatially confined within discrete subcellular domains, thus allowing for selective target activation [80]. To the contrary, loss of subcellular microdomain signalling mechanisms, upon redistribution of compartment restricted components, is perceived in multiple pathophysiological conditions [7,81]. Multiple subcellular components and mechanisms function to define and preserve localized cAMP and cGMP pools, including (i) localization of plasma membrane receptors, (ii) confined distribution of effector targets and (iii) localization of elements restricting secondary messenger diffusion.

(i) Characteristic cardiomyocyte transverse tubules (T-tubules), caveolae and non-caveolae membrane microdomains contribute to ensure compartmentalized signal initiation [82]. Importantly, cholesterol and sphingolipid rich areas in the membrane, called lipid rafts, form gel-like, liquid-ordered domains that hinder membrane fluidity and prevent localized GPCRs to freely diffuse throughout the lipid bilayer [83]. Modern tools combining the use of scanning ion-conductance microscopy (SICM) and Förster resonance energy transfer (FRET) techniques aided to identify domain specific cAMP fluctuations upon generating a detailed topographical image of the cell surface. $\beta_{1}$-AR specific cAMP responses were thereby detected at both T-tubule and non-T-tubule microdomains, whereas cAMP synthesis upon $\beta_{2}$-AR specific 
activation was confined to the T-tubules only [8]. In a similar manner, cGMP responses after specific $\beta_{3}$-AR stimulation were also observed to be restricted to the T-tubules [84]. Besides their influence on membrane fluidity, caveolae/lipid rafts localized within T-tubule and non-T-tubule regions also function to define AC isoform localization. In various cell types, $\mathrm{AC} 1, \mathrm{AC} 3, \mathrm{AC} 5, \mathrm{AC} 6$ and $\mathrm{AC} 8$ were reported to associate with lipid raft domains, while $\mathrm{AC2}, \mathrm{AC4}, \mathrm{AC7}$ and $\mathrm{AC} 9$ were identified within non-raft microdomains [85]. Other studies also demonstrated that the $\beta_{2}$-AR macromolecular complex including Gs, Gi, AC5, AC6 and PKA is specifically localized within caveolar membrane fragments. Contrastingly, $\beta_{1}$-ARs are ubiquitously distributed in both caveolar and non-caveolar compartments in adult rat ventricular myocytes [86-89]. Furthermore, the $\beta_{3}-\mathrm{AR} / \mathrm{eNOS} / \mathrm{sGC}$ macromachinery was also demonstrated to be localized within caveolae-enriched membrane fractions. On the other hand, heart failure contributes to $\beta_{3}$-AR redistribution and altered co-localization of sGC and caveolin-3, disrupting compartmentalized cGMP synthesis [84]. Moreover, caveolae play a fundamental role to mediate appropriate signalling responses in VSMCs and the endothelium. In caveolin-1 deficient mice, impaired endothelium-dependent relaxation and reduced myogenic tone were observed [90,91]. Also, Sampson et al., demonstrated that $\mathrm{K}_{\mathrm{ATP}}$ channels and AC co-localization in rat aortic smooth muscle caveolae is crucial for appropriate $\mathrm{K}_{\mathrm{ATP}}$ channel modulation [92].

(ii) Compartmentalized signalling also relies on the spatial organization of intracellular molecules coupling PKA activity to downstream effector targets as well as signal feedback regulatory elements. A-kinase anchoring proteins (AKAPs) are a superfamily of organizing scaffold proteins which are able to bind PKA and other signalling enzymes, directing their localization to specific cellular compartments $[32,93,94]$. 17 AKAPs have been detected and identified in cardiac tissues coordinating a plethora of signalling components besides PKA including PKC, PDEs, ACs, phosphatases and GTPases. Accordingly, their function has been highlighted to partake in various homeostatic as well as cardioprotective processes including calcium cycling, ECC coupling, heart rhythm and action potential regulation. Additionally, AKAPs coordinate signalling cascades involved in cardiac remodeling responses under pathophysiological settings [94-97]. Several AKAP-specific interactions with multiple AC and PDE isoforms have been identified, supporting precise compartment boundary construction [98-100]. Among others, AKAP79/150 was identified to associate with AC5 and AC6 [98] and mAKAP with AC5 [101]. Moreover, mAKAP was also demonstrated to associate with PDE4D3 [102,103]. Terrenoire et al., could also show that AKAP9 selectively formulates a complex between PDE4D3 and cardiac $\mathrm{I}_{\mathrm{Ks}}$ channels, but not with PDE4D5 [104]. AKAP75 expression has also been demonstrated in VSMC promoting cAMP/PKA signalling [105]. AKAP-dependent PKA interactions with several ion channels (LTCC and $\mathrm{K}_{\text {ATP }}$ ) have also been described in vascular tissue $[106,107]$. Such highly selective interactions mediated via AKAP scaffolds certainly fine tune the elicited intracellular responses. However, further investigations are still required to fully identify specific complex interactions and elucidate their role in cAMP/cGMP signal propagation.

(iii) Localized cyclic nucleotide production alone remains insufficient to account for compartmentalized signalling responses if their diffusion throughout the cytosol is not restricted. Physical cytosolic barriers, cAMP buffering and export mechanisms via cardiac MRP4 efflux protein have been reported to limit cAMP diffusion in the cytosol [108,109]. More importantly, confined cyclic nucleotide distribution via PDE-mediated hydrolysis has been demonstrated in multiple studies [110,111]. 11 PDE subfamilies with over 100 different isoforms and splice variants have been identified [112]. Of the PDE superfamily, PDE1, 2, 3, 4, 5, 8 and 9 are fundamental constituents of the cardiac signalosome coordinating cardiac function under both physiological and pathophysiological conditions [113]. On the other hand PDE1, 2, 3, 4, 5 and 7 constitute the major PDE activity in the vasculature [114,115]. Only PDE2, PDE3 and to a lesser extent PDE1 have been shown to mediate a cGMP/cAMP crosstalk upon modulation of the PDE activities via cGMP. cGMP competitively inhibits the cAMP hydrolytic activity of both PDE1 and PDE3. 
Exceptionally, PDE2 is the only member of the PDE family that is activated upon allosteric cGMP binding, increasing its cAMP hydrolytic activity [110]. In this review, we will particularly focus to discuss PDE2 functional role in the cardiovascular system.

\subsection{PDE2 Molecular Aspects and cGMP/cAMP-Mediated Crosstalk}

PDE2 was first characterized in 1981 as the cGMP-stimulated PDE with dual-substrate specificity for both cGMP and cAMP [116]. PDE2 exhibits similar hydrolyzing maximal velocities and $\mathrm{K}_{\mathrm{m}}$ for both cGMP $(10 \mu \mathrm{M})$ and cAMP $(30 \mu \mathrm{M})$. However in the presence of cGMP, PDE2 hydrolytic activity towards cAMP is uniquely enhanced $~ 5-6$-folds [116]. Native human PDE2 is a protein of 941 amino acids, which functions as a homodimer and is organized in four domains: $N$ terminus (1-214), GAF-A (215-372), GAF-B (393-541) and the catalytic domain (579-941) [117]. So far, two PDE2 genes, PDE2A and PDE2B, have been identified; however PDE2B exists in non-mammalian species and has been characterized in Trypanosoma brucei parasites [118]. Upon transcription, three different splice variants PDE2A1, PDE2A2 and PDE2A3 are constructed [119]. While the three splice forms share similar domain structures, differences arise within the $\mathrm{N}$-terminal domain designating their intracellular localization $[119,120]$. In cardiomyocytes, PDE2A1 was reported to localize in the cytoplasm while PDE2A2 and PDE2A3 are exhibited in particulate and membrane fractions [121]. PDE2A2 localization seems to be confined to the mitochondrial compartment, influencing mitochondrial respiration processes [122]. However, PDE2A has been generally detected in nuclear envelope, Golgi body, plasma membrane and sarcoplasmic reticulum fractions [123-125].

To function as a homodimer, PDE2 monomer dimerization is accomplished via the GAF-A binding locus [126]. The GAF-B domain, on the other hand, modulates PDE2 activity upon cGMP binding $[126,127]$. At sub-saturating cAMP concentrations, cGMP interactions at the GAF-B domain prompt conformational changes at the PDE2 catalytic site leading to a considerable increase in cAMP hydrolysis [126]. Similarly, cAMP can also bind to GAF-B mediating conformational changes, however with a much lower affinity when compared to cGMP ( 21-fold lower). The ability of PDE2 to discriminate between cGMP and cAMP might be in part due to interactions with two amino acids (Phe-438, Asp-439) which enhance cGMP binding but do not favor cAMP interactions [128].

Similar to other PDEs, the alpha-helical architecture of the catalytic domain includes two metal ions, $\mathrm{Mg}^{2+}$ and $\mathrm{Zn}^{2+}$, embedded within the active site in coordination with histidines, aspartic acids, and water molecules $[129,130]$. Diversely, PDE2 uniquely holds two major structural differences within its catalytic site when compared to other PDEs. First, the H-loop has a conformation that results in the occlusion of the substrate-binding site. Secondly, the M-loop is folded away from the substrate-binding site and participates in dimer contacts. In other PDEs, the M-loop is normally folded in towards the binding site. These characteristic conformational properties of PDE2 allows the substrate-binding areas of the monomers to face each other, closing off the access to the substrate-binding site. In this situation, the domain appears to be in a "closed" configuration. However, after cGMP binding to the GAF-B domain, the H-loop swings away and the catalytic domain adopts an "open" configuration, allowing the substrate to bind [117]. Moreover, cAMP and cGMP interact with three hydrophobic sub-pockets within the active site: the pocket containing the glutamine-switch and hydrophobic clamp (Q-pocket), the metal binding pocket (M-pocket), and the solvent-filled side pocket (S-pocket) $[129,130]$. In general, various studies have concomitantly shown that PDE2 can hydrolyze both cAMP and cGMP with similar affinities and kinetics in various myocardial-derived cellular fractions and tissues [131]. However, at higher concentrations each cyclic nucleotide may act as a competitive inhibitor for the other's hydrolysis. At sub-saturating concentrations, cGMP enhances cAMP hydrolysis; however, the reverse may also hold true. Nevertheless, the assumption of cAMP-stimulated cGMP hydrolysis is not very likely to occur in vivo due to the lower cAMP affinity to the GAF-B domain $[128,132]$.

In addition to cyclic nucleotides, PDE2 has also been reputed to associate with scaffold proteins via high-throughput screening studies [133]. PDE2 was shown to interact with XAP2, a crucial 
component of the aryl hydrocarbon receptor (AhR) complex playing an important role in cardiomyocyte differentiation and hypertrophy $[134,135]$. XAP2 targets PDE2 to the AhR complex and thereby inhibits the nuclear translocation of AhR. The carboxyl-terminal part of XAP2 docks to the GAF-B domain of PDE2; nevertheless, allosteric cGMP interactions at the GAF-B domain are not affected [134].

The crosstalk between both cAMP and cGMP pathways is complex and differentially regulated by multiple factors in diverse cardiovascular cell types and within different subcellular microdomains. Crosstalk mechanisms are influenced by the relative abundancy of local cyclic nucleotide levels, in addition to the phosphodiesterase isoforms expressed within a specific microcompartment. At low cGMP concentrations, PDE3 is competitively inhibited limiting its cAMP hydrolytic activity. On the other hand, intermediate levels of cGMP allosterically activate PDE2 mediating a negative cGMP/cAMP crosstalk. At higher cGMP concentrations, PDE1 is potentially inhibited $[110,136]$. Other phosphodiesterases expressed within the myocardium also effectively contribute to regulate cyclic nucleotide levels and have already been investigated as potential therapeutic targets in cardiac disease at a clinical level, e.g., PDE5 $[14,137,138]$. Hereby, Figure 1 illustrates a simplified overview of complex cAMP and cGMP crosstalk mechanisms mediated via PDE2 and influenced by other PDE family members expressed in the cardiovascular system. Nevertheless, multiple studies specifically provided strong evidence for PDE2-mediated negative cGMP/cAMP crosstalk mechanisms in various cardiac cells. For example, NO-stimulated cGMP generation was shown to activate PDE2, enhancing cAMP hydrolysis in neonatal cardiomyocytes as well as in guinea pig pacemaker cells, rat cardiac fibroblasts and human atrial cardiomyocytes [61,139-141]. Additionally, NP/cGMP-induced stimulation of PDE2 enhancing cAMP degradation was reported in rat myocardium [142]. Physiological and pathophysiological consequences of this crosstalk will be further reviewed below.

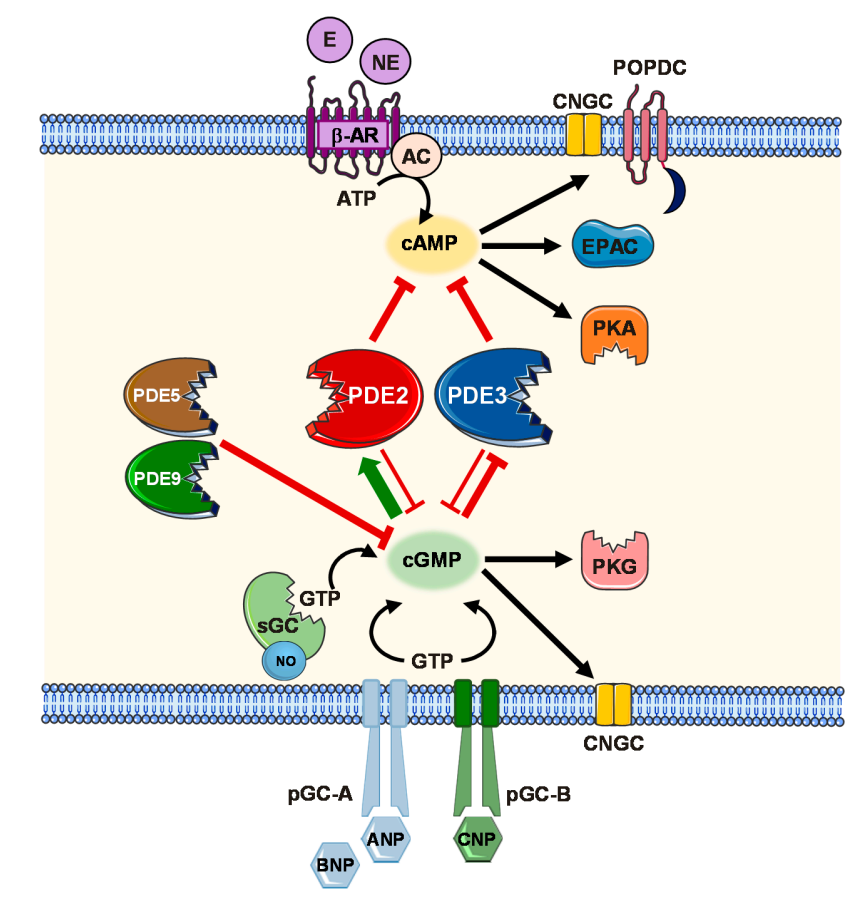

Figure 1. Simplified scheme of phosphodiesterase (PDE)-mediated cGMP/cAMP crosstalk. cAMP generated by adenylate cyclase $(\mathrm{AC})$ upon stimulation of $\beta$-adrenergic receptors leads to the activation of protein kinase $\mathrm{A}$ (PKA) and the family of exchange proteins directly activated by cAMP (EPAC). cGMP generated either by NO-sensitive soluble guanylyl cyclase (sGC) or natriuretic peptide (NP)-sensitive GC-receptors leads to the stimulation of cGMP-dependent protein kinase G (PKG). In diverse subcellular compartments, cGMP stimulates phosphodiesterase 2 (PDE2) but competitively inhibits PDE3-mediated cAMP hydrolysis. PDE5 and PDE9 degrade cGMP in cardiomyocytes. Figure was produced using Servier Medical Art (Available online: http://smart.servier.com). 


\section{PDE2 Functions in the Cardiovascular System}

Within the cardiovascular system, PDE2 is predominantly expressed in endothelial cells and in cardiac fibroblasts but is modestly expressed in cardiomyocytes under physiological conditions $[133,143,144]$. Prominent PDE2 expression is notable in various neuronal cell types within the central nervous system and thereby PDE2 activity in sympathetic neurons also modulates the cardiac function [145-148]. Furthermore, PDE2 activity was also demonstrated in circulating immune cells, e.g., monocytes, macrophages and lymphocytes [149-152]. In human and rodent monocytes, the macrophage colony-stimulating factor (M-CSF) was shown to induce PDE2 expression in monocytes differentiating in peritoneal macrophages $[149,150]$. Additionally, the cytokine tumor necrosis factor- $\alpha$ (TNF- $\alpha$ ) was also reported to induce the expression of PDE2 and contribute to increase endothelial permeability [153]. Thereby, in the following sections we will focus to discuss the function of PDE2 within the myocardial tissue under both physiological and pathophysiological conditions.

\subsection{Cardiomyocytes}

Despite the limited expression of PDE2 in cardiomyocytes and its modest contribution to the total cAMP hydrolytic activity $(\sim 3 \%)$ under physiological conditions, PDE2 remains a well-recognized and important modulator of cardiac function $[131,133,154]$. PDE2 has been shown to finely coordinate critical cAMP pools governing $\beta$-AR signalling, cardiomyocyte contractility, $\mathrm{Ca}^{2+}$ homeostasis and mitochondrial function (Figure 2) [122,154,155].

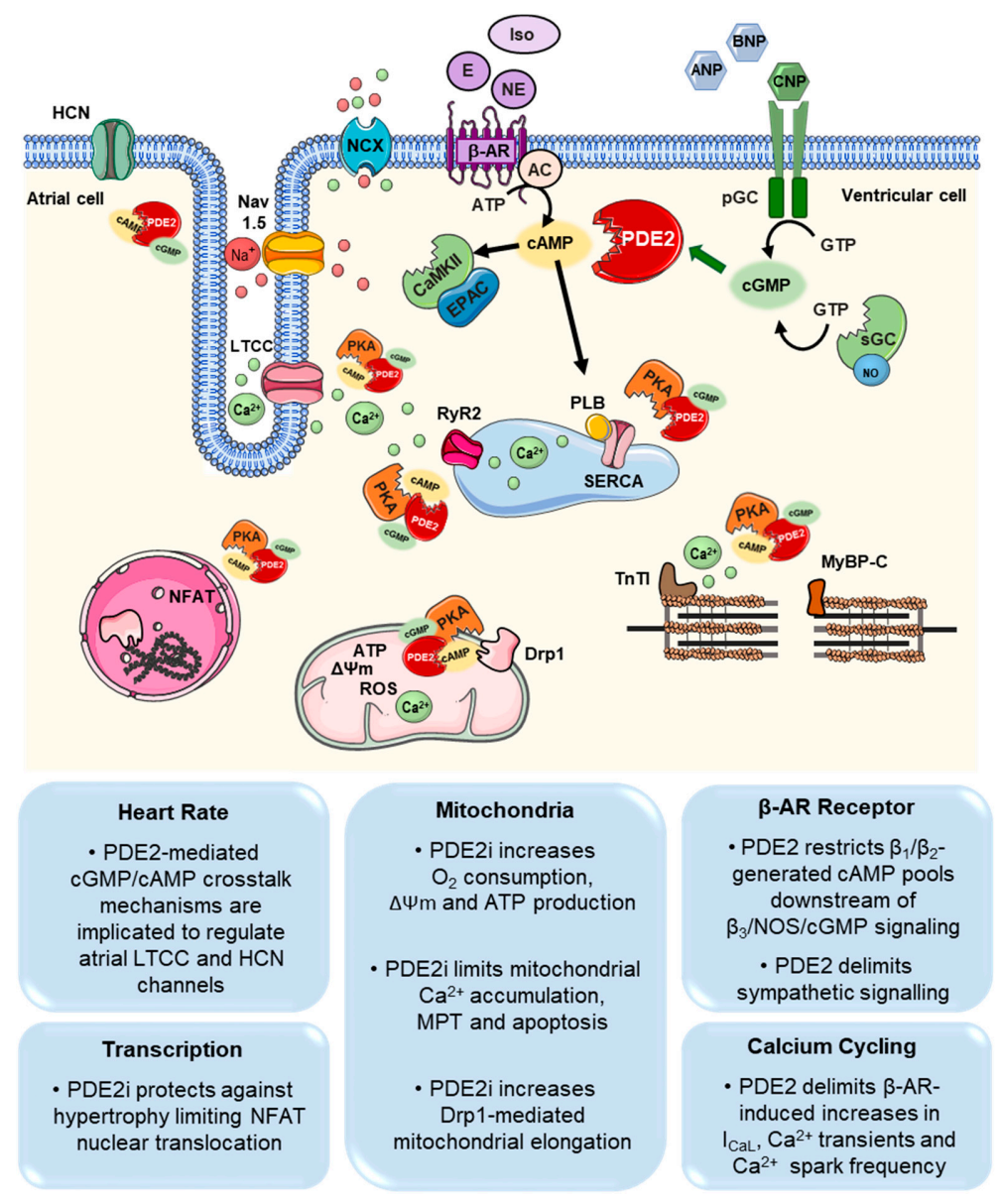

Figure 2. PDE2-mediated cGMP/cAMP crosstalk mechanisms in cardiomyocytes. PDE2 regulates cAMP levels downstream of $\beta$-AR signalling at a compartmentalized level, modulating PKA- and potentially 
EPAC/CaMKII-mediated activation of numerous targets. First, PDE2 regulatory activities are detected at the plasmalemma, modulating $\mathrm{I}_{\mathrm{Ca}, \mathrm{L}}$ and possibly $\mathrm{HCN} \mathrm{I}_{\mathrm{f}}$ currents. Additionally, PDE2 regulates components of the ECC machinery at the SR (RyR2 and PLB) and sarcomeres (TnT1 and MyBP-C). PDE2 transcriptional regulatory effects are also reported in the nuclear compartment in addition to its role to regulate mitochondrial function and dynamics. PDE2 is also activated by cGMP synthesized downstream of both sGC and pGC, to promote a negative cGMP/cAMP crosstalk mechanisms in the aforementioned compartments. (PDE2 inhibition (PDE2i)) Figure was produced using Servier Medical Art (Available online: http://smart.servier.com).

PDE2 seems to closely couple with the $\beta$-AR family in cardiomyocytes. Mongillo et al., could show that PDE2 finely coordinates $\beta_{1} / \beta_{2}$-AR-generated cAMP pools downstream of the $\beta_{3}$-AR/NO pathway. While PDE2 inhibition leads to a minor increase in intracellular cAMP levels under basal conditions, a marked increase in norepinephrine-induced $[\mathrm{cAMP}]_{\mathrm{i}}$ responses was observed following PDE2 inhibition ( 7-folds). Hereby, the abolished cAMP restriction indicates that $\beta$-AR-generated cAMP pools are strictly defined by PDE2. A key mechanism partly contributing to increased PDE2 activity within this compartment was attributed to norepinephrine-mediated activation of $\beta_{3}$-AR. This subsequently potentiates the eNOS/NO/cGMP signalling cascade and activation of PDE2 [124]. In heart failure, Schobesberger et al., could demonstrate that PDE2-mediated cGMP/cAMP crosstalk mechanisms downstream of $\beta_{3}$-AR signaling pathways were impaired due to altered $\beta_{3}$-AR and sGC distribution [84].

The regulatory role of PDE2 in shaping $\beta$-AR responses is also associated with refined phosphorylation of downstream kinase targets like LTCCs, troponin I and MYBPC $[155,156]$. Earlier investigations highlighted a role for PDE2 in L-type $\mathrm{Ca}^{2+}$ current $\left(\mathrm{I}_{\mathrm{Ca}, \mathrm{L}}\right)$ modulation, particularly in the human myocardium. Rivet et al., could display an increase in $\mathrm{I}_{\mathrm{Ca}, \mathrm{L}}$ upon PDE2 selective inhibition with EHNA in human atrial myocytes [157]. Similarly, multiple groups also indicated reduced $\mathrm{I}_{\mathrm{Ca}, \mathrm{L}}$ upon cGMP-induced activation of PDE2. Reduced $\mathrm{I}_{\mathrm{Ca}, \mathrm{L}}$ in this setting was attributed to lower LTCC phosphorylation at PKA specific sites due to the diminished cAMP levels in this compartment $[141,156,158]$. Consequences of attenuated $\mathrm{I}_{\mathrm{Ca}, \mathrm{L}}$ upon PDE2-mediated cAMP degradation are associated with the regulation of cardiac heart rate and cardiomyocyte contractility. In pacemaker cells, NO-induced heart rate modulation was shown to be partly dependent on cGMP/PDE2 activation and finally $\mathrm{I}_{\mathrm{Ca}, \mathrm{L}}$ attenuation $[110,159]$. Furthermore, Mongillo et al., demonstrated that PDE2 potently modulates cardiomyocyte contractility following $\beta$-AR stimulation in rat ventricular myocytes [124]. The increased cGMP synthesis following sodium nitroprusside (SNP) treatment provoked PDE2 activation and consequently abrogated norepinephrine-induced increase in cAMP amplitudes by $50 \%$. Thereby, PDE2 inhibition amplified norepinephrine- and isoprenaline-induced increase in $\mathrm{Ca}^{2+}$ transients and fractional shortening [124]. Likewise, Mika et al., showed increased $\mathrm{Ca}^{2+}$ transients, sarcomere shortening and enhanced MYBPC3 phosphorylation after specific PDE2 inhibition with BAY60-7550 [155]. Correspondingly, mice with cardiac-specific PDE2 overexpression exhibited lower heart rates and displayed blunted isoprenaline-induced increases in cAMP levels as well as in $\mathrm{I}_{\mathrm{Ca}, \mathrm{L}}, \mathrm{Ca}^{2+}$ transients and sarcomere shortening [17]. Redistribution of PDE2, as well as PDE3, within $\beta$-AR microdomains has been reported in heart failure animal models, influencing cardiac responses and contractility [7,160]. Relocalization of PDE2 from $\beta_{1}$-AR-associated noncaveolar into $\beta_{2}$-AR-containing caveolar fractions was demonstrated in cardiac hypertrophy after transaortic constriction [7]. Additionally, the PDE3-induced hydrolysis of cAMP downstream of $\beta_{2}$-ARs within the phospholemman/sodium-potassium ATPase microdomain was diminished after MI-induced chronic heart failure in rats. However, a significant increase in PDE2-mediated effects was thereafter recognized in this compartment confirming PDE2 and PDE3 relocalization in heart failure [160].

Apart from $\beta$-AR signalling and ECC regulatory functions, PDE2 is also associated with critical signalling pathways modulating cardiomyocytes' energetic capacities and apoptosis. Liu et al., highlighted that in the presence of cGMP, PDE2 holds the largest mitochondrial cAMP-degrading activity when compared to PDE3 and PDE4 in adult rat ventricular myocytes. They also demonstrated 
the PDE2 specifically localizes within subsarcolemmal mitochondria associated with the mitochondrial inner membrane [161]. Upon PDE2 inhibition with BAY60-7550, elevated mitochondrial cAMP levels were recognized, implicating an increase in oxygen consumption, mitochondrial membrane potential $(\triangle \Psi \mathrm{m})$ and ATP production [161-163]. Additionally, cAMP is rate-limiting for matrix $\mathrm{Ca}^{2+}$ entry via the exchange factor EPAC1 and the mitochondrial $\mathrm{Ca}^{2+}$ uniporter and thus abrogates mitochondrial permeability transition (MPT). Collectively, the latter effects contribute to protect against cardiomyocyte cell death and apoptosis [163]. Accordingly, mice with cardiomyocyte specific PDE2 overexpression exhibited faster $\Delta \Psi \mathrm{m}$ loss and mitochondrial swelling [161]. PDE2 was further shown to mediate intracellular effects of estrogens. In a rat cardiomyoblast cell line, $17 \beta$-estradiol reduced mitochondrial cAMP levels via cGMP-mediated stimulation of PDE2, finally decreasing cytochrome oxidase activity and mitochondrial membrane potential [164].

On the other hand, Monteresi et al., showed that mitochondrial PDE2A2 regulates cAMP pools localized at the outer mitochondrial membrane. This specific cAMP compartment was found to modulate the activity of the dynamin related protein 1 (DRP1) fission protein. PDE2 inhibition, and thereby elevated cAMP levels, enhanced PKA-dependent phosphorylation of DRP1. Elongated mitochondria were therefore notable due to diminished DRP1 fission activity. With such an elongated morphology, mitochondria exhibited increased $\Delta \Psi \mathrm{m}$, protecting the cardiomyocytes against apoptotic cell death [122].

\subsection{Fibroblasts}

PDE2 is more abundantly expressed in cardiac fibroblasts when compared to cardiomyocytes. Thereby, studying PDE2 functions in fibroblasts is of importance since fibroblasts constitute the major nonmyocyte component of the cardiac tissue comprising $65 \%$ of the heart cell number [165]. Early studies clearly highlighted PDE2-mediated cGMP/cAMP crosstalk mechanisms in adult rat fibroblasts, particularly in an inflammatory milieu. Gustafsson and Brunton first demonstrated that IL-1 $\beta$ induces iNOS expression in cardiac fibroblasts. Simultaneous IL-1 $\beta$ treatment and $\beta$-AR stimulation was found to stabilize iNOS mRNA, increasing the IL-1 $\beta$-induced NO-production in the fibroblasts [166]. Later on, the authors provided evidence for an induction of a PDE2-dependent cGMP/cAMP crosstalk under these conditions. IL-1 $\beta$-induced iNOS expression enhances NO/cGMP production and in turn activates PDE2, attenuating cAMP accumulation after isoprenaline or forskolin treatment [140]. However, reduced cAMP levels may mediate alternative consequences in distinct cell types of the myocardium that may not always be favorable. In fibroblasts, diminished cAMP signalling promotes fibrotic effects, cell proliferation and collagen production [167]. In line with these publications, PDE2 overexpression in cardiac fibroblasts accelerated cAMP degradation and subsequently supported fibroblast activation and transformation into myofibroblasts. Increased $\alpha \mathrm{SMA}$ and CTGF profibrotic factors were observed upon PDE2 overexpression (Figure 3). These events finally resulted in higher stiffness of fibroblast-derived engineered connective tissues [144]. Therefore, PDE2 activity in distinct cardiac cells displays controversial effects within the myocardium.

\subsection{Sympathetic Neurons}

As previously introduced, PDE2 plays a crucial role in cardiac sympathetic neurons [145]. In dissociated sympathetic neurons from stellate ganglia, adenoviral-nNOS overexpression augmented cGMP levels; however, cAMP levels were consequently reduced. Diminished cellular cAMP levels subsequently inhibited $\mathrm{Ca}^{2+}$-influx via voltage-gated $\mathrm{Ca}^{2+}$ channels and thereby decreased exocytotic norepinephrine release. Adenoviral-nNOS-induced reduction in cAMP levels was reversed when cells were treated with the PDE2 inhibitor BAY60-7550, suggesting that PDE2 is the main cAMP-hydrolyzing enzyme in these cells [145]. PDE2 activity was also reported to be increased in stellate ganglion derived from patients with a sympathetic overdrive and ventricular arrhythmias. This also implicates that selective targeting of neuronal PDE2 may offer a novel potential therapeutic strategy in sympathetic hyperactivity disease settings [147]. 


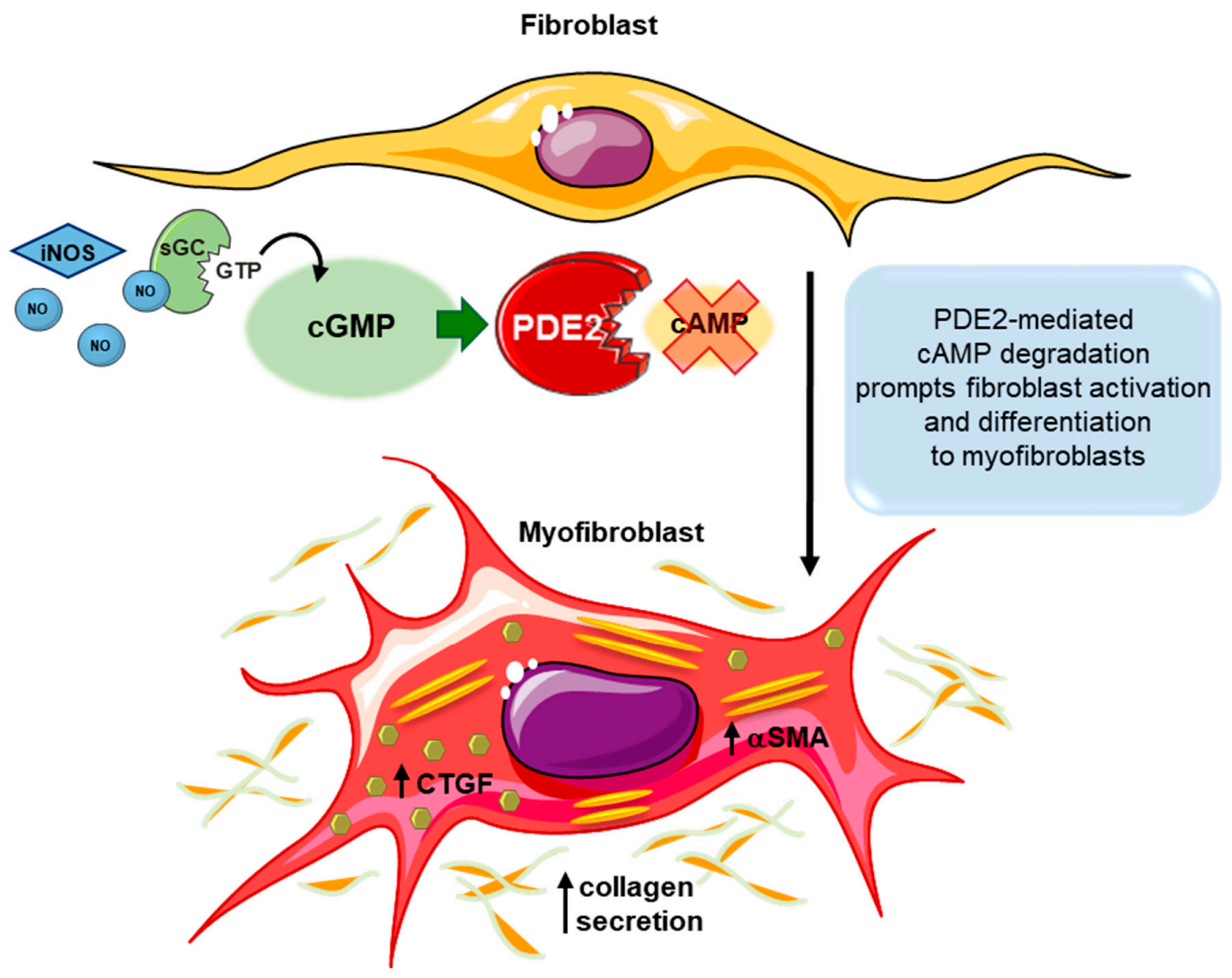

Figure 3. Schematic illustration of the PDE2-mediated cGMP/cAMP crosstalk in cardiac fibroblasts. PDE2 overexpression or enhanced activity subsequent to iNOS/NO/cGMP stimulation accelerates cAMP hydrolysis in cardiac fibroblasts. Diminished cAMP levels prompt fibroblast activation and differentiation into myofibroblasts promoting $\alpha$-smooth muscle actin ( $\alpha \mathrm{SMA})$, connective tissue growth factor (CTGF) and collagen disposition, increasing muscle stiffness. Figure was produced using Servier Medical Art (Available online: http://smart.servier.com).

\subsection{Vasculature and Circulating Blood Cells}

As summarized previously, PDE2 activity was detected in circulating immune cells, e.g., monocytes, macrophages and lymphocytes [149-152]. Additionally, along with PDE3 and PDE5, PDE2 is also expressed in platelets playing an important role to regulate platelet activation. RNA-sequencing analysis revealed that PDE2A2 is the predominantly expressed variant of PDE2 in human platelets [168,169]. Both cAMP and cGMP inhibit multiple signalling cascades involved in platelet activation, including degranulation, fibrinogen receptor activation, cytoskeletal rearrangement and expression of proinflammatory mediators. Thereby PDE inhibitors have been considered for antiplatelet therapy [170]. Antiplatelet effects of PDE3 and PDE5 inhibitors have been proven clinically and currently approved for intermittent claudication (cilostazol, PDE3 inhibitor) and coronary vasodilatation with antiplatelet activity (Dipyridamole, PDE3/5 inhibitor) $[169,170]$. PDE2 inhibitors have not been tested for clinical use; however, preclinical studies highlighted attenuated platelet activity upon PDE2 inhibition. PDE2 inhibition with EHNA was demonstrated to potentiate the inhibitory effects of nitroprusside on thrombin-induced platelet aggregation [171]. The effect of other PDE2 inhibitors, such as BAY60-7550 and PDP, on platelet aggregation remains to be investigated. Further studies are needed to prove if PDE2 might be a potential target for antiplatelet therapy in thrombotic and ischemic conditions.

Although PDE2 is not primarily expressed in vascular smooth muscle cells, PDE2 is rather highly expressed in endothelial cells $[76,143,172]$. A comprehensive discussion of PDE2 effects in endothelial 
cells and its impact on angiogenic and inflammatory responses under ischemic and septic cardiac conditions is elaborated in Sections 4.3-4.5 and illustrated in Figure 4.

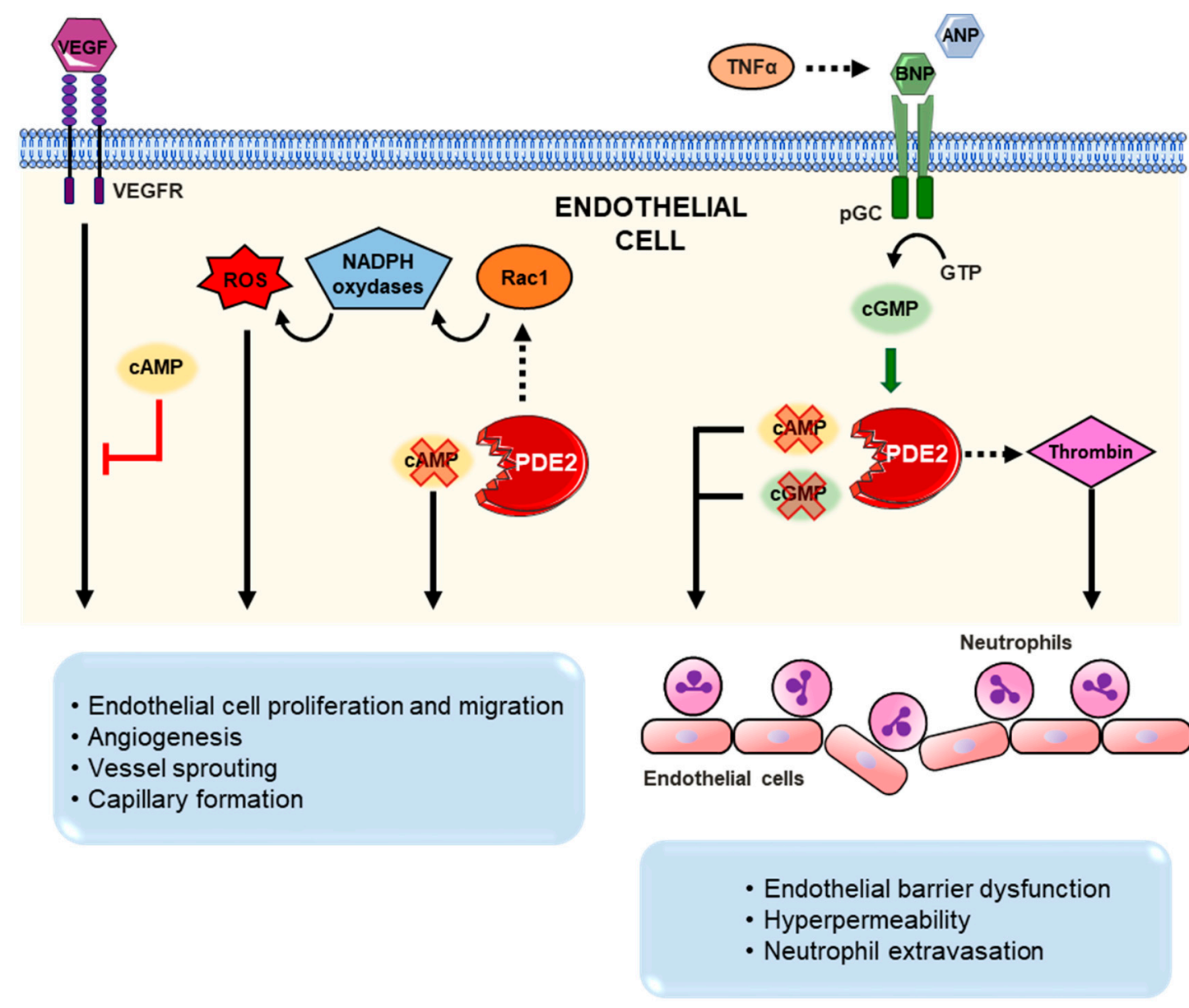

Figure 4. Schematic illustration of the PDE2-mediated cGMP/cAMP crosstalk in endothelial cells. PDE2 stimulates endothelial cell proliferation and angiogenesis by hydrolyzing cAMP (which reduces cell proliferation) and stimulating ROS production through Rac1 and NADPH oxidases, inducing cell proliferation and angiogenesis together with VEGF. TNF- $\alpha$ promotes BNP, increasing cGMP level; consequently, cGMP activates PDE2 cAMP and cGMP hydrolyzing activity and PDE2 also stimulates thrombin. This results in enhanced neutrophil infiltration, increasing inflammation. Figure was produced using Servier Medical Art (Available online: http://smart.servier.com).

\section{Role of PDE2 in Cardiovascular Disease}

\subsection{Arrhythmia (Atria, Ventricular, Sinus Node)}

Onset of lethal cardiac arrhythmias leading to sudden cardiac death is the most frequent cause of mortality in heart failure patients. Unfortunately, currently available antiarrhythmic pharmacotherapies are of low therapeutic indices and often intrinsically dispose proarrhythmogenic effects upon brief use [173]. The clinical use of some PDE inhibitors in heart failure, such as milrinone (PDE3 inhibitor), is limited as they have been associated with increased arrhythmogenic susceptibility [174]. Contrastingly, PDE2 seems to play a unique role in heart rate regulation and appears to provide protection against arrhythmia onset [17].

Recently, Vettel et al., could show that pharmacological PDE2 inhibition in vivo lead to an exclusive elevation in heart rates of beagle dogs and amplified $\beta$-AR-induced chronotropic responses in mice. Accordingly, transgenic animals with cardiomyocyte specific PDE2A3 overexpression (TG) exhibited 
lower basal heart rates. More importantly, increased PDE2A3 abundancy protected the animals against arrhythmogenesis upon cardiac stress. TG animals were resistant to triggered ventricular arrhythmias induced by catecholamine injections. Moreover, PDE2A3 overexpression remarkably protected TG mice against arrhythmia-induced early death after MI. These intriguing results were attributed to reduced RyR2 phosphorylation at the pro-arrhythmic CaMKII specific site (RyR2 Ser2814) as well as reduced $\mathrm{I}_{\mathrm{Ca}, \mathrm{L}}$ and $\mathrm{Ca}^{2+}$ transients achieved after $\beta$-AR stimulation. The authors could thereby confirm that PDE2A3 overexpression protected against catecholamine-induced increase in RyR2 leak; and thereby lower $\mathrm{Ca}^{2+}$ wave and spark frequencies were observed in cardiomyocytes isolated from TG animals when compared to their wild type littermates [17].

Given the limitations of transgenic overexpressing mouse models, particularly in the case of PDEs, where isoform specific compartmentalized expression may be perturbed, supporting investigations in PDE2-KO animals are still required. Unfortunately, global PDE2 deletion resulted in premature embryonic death (before E16). Nevertheless, documented findings in PDE2-KO embryos highlighted a critical role for PDE2 in heart rhythm regulation and cardiac development. Isolated cardiomyocytes from the fetal PDE2-KO hearts indicated higher beating frequencies; but beating was arrested more frequently when compared to control animals suggesting an increased susceptibility towards arrhythmias. Moreover, PDE2 deficiency led to embryonic nuchal edema and thereby enlarged hearts were recognized. Also, diminished atrial chamber trabeculae, impaired interventricular septum and myocardial wall defects were detected in KO embryos [175].

With the eminent impact of PDE2 on heart rate regulation and arrhythmia susceptibility, a regulatory role for PDE2 at the sinus node is suspected. Hua et al., could show that PDE2, and also PDE4, play a role in modulating action potential firing frequency in isolated cardiomyocytes from mice. Both PDEs regulate the $\mathrm{I}_{\mathrm{Ca}, \mathrm{L}}$ more prominently in murine cardiomyocytes from sinus node and atrium compared to ventricular myocytes [176]. Another study implicated a possible role for PDE2 in the regulation of the sinus hyperpolarization-activated current $\left(\mathrm{I}_{\mathrm{f}}\right)$. The investigators demonstrated that $\mathrm{SNP} / \mathrm{NO} / \mathrm{cGMP}$-induced a transient increase in heart rate upon simultaneous $\beta$-AR stimulation due to potential cGMP-dependent stimulation of $\mathrm{I}_{\mathrm{f}}$. Additional PDE2 inhibition amplified SNPmediated heart rate responses, implicating that cGMP-induced activation of PDE2 limits SNP-induced heart rate effects [139]. On the other hand, PDE2A3-TG did not highlight altered activity of the cyclic nucleotide gated HCN channels. A similar decrease in heart rate was observed upon HCN blockade with ivabradine in both PDE2A3-TG and WT littermates, rather indicating an impact of PDE2 on sinus $\mathrm{Ca}^{2+}$ clock [17]. Further studies are needed to evaluate the direct influence of PDE2 inhibition on HCN activity expanding our understanding regarding the role of PDE2 on heart rate regulation. Nevertheless, in the murine sinoatrial node, a crosstalk between the cGMP-degrading PDE5 and cGMP-stimulated PDE2 was demonstrated to modulate $\beta$-AR-induced chronotropic responses. Isidori et al., described that specific cAMP pools generated downstream of $\beta_{2}$-ARs are finely regulated by PDE2 and indirectly by PDE5. Inhibition of PDE5 promoted cGMP-dependent activation of PDE2. Thereafter, $\beta$-AR-generated cAMP pools were attenuated mediating negative chronotropic effects with concomitant modulation of calcium transients [177]. Intact PDE2 activity is therefore crucial to maintain appropriate heart rate responses to various neurohormonal stimuli.

\subsection{Hypertrophy, Heart Failure}

The role of PDE2 in heart failure and cardiac remodeling remains obscure. Contradictory findings in diverse experimental settings reflect the complex integrity of PDE2 and its involvement in regulation of multiple signalling cascades that may seem to counteract each other. Mehel et al., were the first to point out that PDE2 is upregulated in the human failing myocardium [16]. Patients suffering from end-stage dilated cardiomyopathy or ischemic cardiomyopathies exhibited $\sim 2$-fold increase in PDE2 protein levels when compared to the non-failing control group. However, PDE2 expression was not altered in hypertrophied myocardium from patients with preserved cardiac function (ejection fraction $>50 \%$ ) who underwent aortic valve replacement due to aortic stenosis [16]. In diverse experimental 
animal models, PDE2 upregulation was shown to be closely associated with cardiac disease progression, cardiac arrhythmia onset and heart failure. PDE2 expression was elevated in a canine model of rapid pacing-induced heart failure as well as in rodent models subjected to chronic minipump catecholamine infusions or pressure overload via transverse aortic constriction $[16,178]$. These findings implicated that PDE2 contributes to the myocardial $\beta$-AR desensitization process and protects the damaged heart from excessive sympathetic stress. Blunted $\beta$-AR responses were confirmed upon adenoviral PDE2A2 overexpression in adult rat ventricular myocytes, which resulted in reduced cAMP levels, $\mathrm{I}_{\mathrm{Ca}, \mathrm{L}}, \mathrm{Ca}^{2+}$ transients and abrogated inotropic effects following acute $\beta$-AR stimulation without affecting basal contractility. Notably, adenoviral PDE2A2 overexpression also protected the cardiomyocytes against norepinephrine-induced hypertrophic growth [16].

To the contrary, opposing results were presented by Zoccarato et al., highlighting hypertrophic responses upon adenoviral overexpression of the PDE2A2 in neonatal rat ventricular cardiomyocytes. The group displayed that rather PDE2 inhibition counteracted the hypertrophic growth in vitro. Supporting data from mice subjected to transverse aortic constriction demonstrated protection against cardiac hypertrophy upon PDE2 inhibition in vivo with BAY60-7550. The antihypertrophic effects recognized after PDE2 inhibition were attributed to cAMP-induced activation of PKA type II subset. The latter subsequently increases NFAT phosphorylation, thereby preventing its nuclear translocation and thus prohibiting hypertrophic signalling [18]. In a different setting, Baliga et al., also reported hindered adverse cardiac remodeling responses upon PDE2 blockade with BAY60-7550. In an alternative manner, PDE2 inhibition promotes cGMP signalling and ameliorates pathological left ventricular hypertrophy and fibrosis, improving cardiac contractility in a pressure overload heart failure model or post sympathetic hyperactivation. Using multiple transgenic animal models, the authors concluded that PDE2 inhibition preferentially enhances NO/sGC/cGMP signalling rather than ANP or BNP/pGC/cGMP cascades in heart failure settings to mediate these protective effects [19]. Other mechanisms have also been proposed, highlighting a role PDE2 in regulating the PLC $/$ /PI4P-mediated hypertrophic pathway. PDE2 inhibition has been hypothesized to promote PKA-dependent phosphorylation and thereby inhibition of PLCE. Diminished PLC $\varepsilon$-induced PI4P hydrolysis in the Golgi apparatus thus abrogates hypertrophic signalling [179].

In summary, recent studies seem to support that PDE2 inhibition promotes antihypertrophic responses. Nevertheless, the conflicting findings reviewed here, indicate that the role of PDE2 in hypertrophic remodeling should be conclusively verified and careful experimental designs should be constructed. Of course, disparate experimental methods and conditions may underlie the observed incoherent results [180], yet PDE2 is evidently a valuable therapeutic target to preclude cardiac remodeling events.

\subsection{Myocardial Infarction (MI)/Reperfusion Injury}

In patients suffering from MI, ischemia duration is critical, influencing the extent of myocardial hypoxia and cell necrosis. Management of myocardial infarcts remains a challenge in the cardiovascular field as with current interventions reperfusion injuries are difficult to circumvent. Post reperfusion, sarcolemmal rupture often occurs during the first few minutes upon restoring blood flow, thereby activating apoptotic and necrotic processes in cardiomyocytes [181]. Also, mitochondrial dysfunction, due to excessive mitochondrial $\mathrm{Ca}^{2+}$ accumulation, mitochondrial permeability transition and increased ROS production, has been implicated to mediate necrotic processes in ischemia reperfusion injuries. Thereby, therapeutic strategies supporting mitochondrial function may ameliorate the reperfusion damage [182,183]. Rinaldi L. et al., showed that PDE2 inhibition could protect against cell necrosis during ischemia reperfusion. The group initially demonstrated that diminished mitochondrial cAMP content is detrimental and exacerbates reperfusion damage post ischemia. On the other hand, overexpression of sAC improves cardiac cell viability [184]. Elevated mitochondrial cAMP content subsequently promotes PKA-dependent phosphorylation and activation of cytochrome c oxidase, enhancing ATP synthesis and attenuates ROS production as reported previously $[184,185]$. PDE2 
inhibition during reperfusion and ischemia resulted in a specific increase in mitochondrial cAMP content, improved cell survival and accelerated recovery of cytosolic $\mathrm{Ca}^{2+}$ homeostasis [184].

Another study investigated if endogenously elevated ANP levels could limit infarct size after subjecting KO mice with endothelial GC-A deletion to MI [186]. NP-mediated GC-A/cGMP signalling was previously demonstrated to improve endothelial barrier properties downstream of cGMP-dependent kinase 1 (cGK1) under acute inflammatory conditions [187]. Unexpectedly, myocardial infarct size and immune cell infiltration two days after MI were attenuated in $\mathrm{KO}$ animals. These intriguing findings were attributed to PDE2 upregulation in the left ventricular myocardium, induced by hypoxia-mediated secretion of the inflammatory cytokine TNF- $\alpha$. Elevated ANP levels in the diseased myocardium of WT animals promoted PDE2-cGMP/cAMP crosstalk, thus diminishing endothelial cAMP content. Reduced cAMP levels thereby hindered proper cardiac endothelial barrier function and induced capillary hyperpermeability. Endothelial GC-A deletion protected from PDE2 crosstalk mechanisms, attenuating infarct size. The authors therefore concluded that endothelial PDE2 inhibition might provide beneficial effects after MI [186].

\subsection{Angiogenesis}

Angiogenesis is a critical process coordinating new vessel formation from preexisting ones to maintain a sufficient oxygen supply during cardiac developmental and remodeling processes. Although the heart size remains rather stable during adulthood, the heart still retains a capacity for growth to sustain the cardiac output following physiological and pathophysiological increases in workload. In physiological reversible hypertrophy, arising during pregnancy or exercise training, proportional increases in cardiomyocyte size and angiogenic vessel development is achieved to preserve the oxygen supply. On the other hand, impaired angiogenic vessel enlargement and sprouting is a typical feature in pathological cardiac remodeling [188-190]. Angiogenesis inhibition in animal models of overload-induced cardiac hypertrophy resulted in early onset of heart failure [190]. To the contrary, delayed heart failure development was recognized after promoting angiogenic mechanisms [191].

The cardiomyocyte signalosome includes multiple cardiokines such as the vascular endothelial growth factor (VEGF), which promotes angiogenic processes via induction of endothelial cell proliferation and migration. Elevated cAMP levels in endothelial cells have been shown to inhibit VEGF-induced proliferation. A role for PDE2 and PDE4 was established to regulate this process in noncardiac endothelial derived cells [172]. So far, only the use PDE5 inhibitors, e.g., vardenafil, has been evaluated in a unilateral hindlimb ischemia model which showed that PDE5 inhibition enhances ischemia-induced angiogenesis [192]. Therefore, it would be interesting to study the role of PDEs, including PDE2 in ischemic cardiac diseases settings.

In vitro investigations in human umbilical vein cells (HUVEC) illustrated that PDE2 inhibition resulted in elevated cAMP levels after stimulation with VEGF. In turn, cell proliferation, entry to G2/M cell cycle phase and also cell migration were all hindered. Additionally, simultaneous inhibition of PDE2 and PDE4 in chicken embryos reduced angiogenesis in vivo [172]. Another study conducted by Diebold et al., also highlighted a role of PDE2 in ROS-induced endothelial cell proliferation and migration. PDE2 overexpression in HUVEC increased the activation of the GTPase Rac1, triggering NADPH oxidases to enhance ROS production. The latter consequently promoted cell proliferation and in vitro capillary formation. On the other hand, PDE2 inhibition or downregulation prevented ROS-induced HUVEC proliferation in vitro, vessel sprouting in mouse aortic explants ex vivo and angiogenesis in subcutaneous HUVEC Matrigel plug implantations in vivo [193]. Collectively, these studies could demonstrate a prominent role for PDE2 to modulate vascular dynamics. Nevertheless, further investigations are required to evaluate PDE2 as a therapeutic target in cardiovascular hypoxia and ischemic conditions stimulating angiogenesis. 


\subsection{Inflammation/Sepsis}

After acute MI, hypoxia and elevated cytokine levels induce leukocytes infiltration in the myocardial tissue prompting cardiac inflammation. Neutrophils initiate the acute inflammatory response, whereas excessive infiltration increases the release of inflammatory mediators and kinases, contributing to tissue injury [186]. In HUVEC, TNF- $\alpha$ was shown to induce an increase in PDE2 expression levels. Likewise, in postcapillary venules within the mouse cremaster muscle, TNF $\alpha$ also promoted PDE2 expression and enhanced PDE2-mediated cGMP/cAMP crosstalk upon NP treatment. Augmented cAMP hydrolysis thereby provoked hyperpermeability and induced endothelial barrier dysfunction promoting neutrophil infiltration after MI. To the contrary, genetic GC-A deletion and pharmacological PDE2 inhibition prevented ANP-induced hyperpermeability in the TNF- $\alpha$ treated mice. In conclusion, PDE2 inhibition provides protective anti-inflammatory effects after MI limiting endothelial barrier permeability and leukocyte infiltration [186].

In line with these results, Seybold et al., also demonstrated TNF- $\alpha$-induced increase in PDE2 expression in HUVECs under septic conditions [153]. Sepsis is a systemic inflammatory response characterized by increased endothelial barrier permeability due to enhanced TNF- $\alpha$ and thrombin secretion. TNF- $\alpha$ and thrombin promote platelet and leukocyte adhesion and provoke the secretion of inflammatory cytokines. The study demonstrated that TNF- $\alpha$ stimulated PDE2 expression upon activation of p38 mitogen-activated protein kinase (MAPK). PDE2 upregulation contributed to destabilize the endothelial barrier integrity and sensitized HUVECs towards the permeability-increasing agent thrombin. On the other hand, PDE2 selective inhibition significantly reduced edema formation in mice lungs and reduced lung permeability. At the molecular level, PDE2 inhibition also reduced TNF- $\alpha$ and thrombin-mediated alterations in endothelial F-actins and redistribution of VE-cadherin [153].

Furthermore, Neviere et al., indicated that PDE2 inhibition in septic cardiac fibers was beneficial as it limited sepsis-induced myocardial dysfunction and improved mitochondrial respiration [194]. Since sAC-induced cytochrome c oxidase phosphorylation is PKA-dependent, PDE2 inhibition partially increased cytochrome c oxidase subunit IV-1 protein phosphorylation in septic cardiac fibers. This led to an increase in respiratory control ratios, improved myocardial oxygen uptake efficiency and mitochondrial respiration. Moreover, perfusion of isolated septic hearts with the PDE2 inhibitor BAY60-7550 increased left ventricular developed force. Consistently, pretreatment with BAY60-7550, prior to a cecal ligation puncture procedure to induce sepsis, also significantly reduced coronary perfusion pressure and improved cardiac efficiency in septic mice in vivo [194]. Collectively, PDE2 inhibition improves myocardial function in septic hearts by maintaining endothelial barrier integrity and improving mitochondrial respiration.

\subsection{Pulmonary Hypertension}

Pulmonary hypertension $(\mathrm{PH})$ affects the pulmonary vasculature due to the sustained elevation of pulmonary arterial pressure and remodeling of small pulmonary arteries [195,196]. PH is often associated with right ventricular heart failure and patients frequently exhibit sever signs of dyspnea [197]. Thereby, according to the National Heart Lung and Blood Institute of the National Institutes of Health (NIH), heart failure is one of the most common causes of death in patients with $\mathrm{PH}$.

The most effective strategy to alleviate PH symptoms is to promote both cGMP and cAMP signalling enhancing vasodilation $[196,198,199]$. While PDE5 inhibitors have been extensively studied for clinical use to treat PH $[198,200,201]$, PDE2 has not been comprehensively investigated and only one study demonstrated that PDE2 inhibition may ameliorate PH [196]. In this study, the authors demonstrated that PDE2 inhibition with BAY60-7550 prevented the onset of both hypoxia- and bleomycin-induced PH. BAY60-7550 treatment reduced the right ventricular systolic pressure, right ventricular hypertrophy and limited the number of muscularized pulmonary arteries. Protective effects achieved upon PDE2 inhibition were further augmented in the presence of cGMP- (sildenafil, inorganic nitrate) or cAMP- (i.e., treprostinil) enhancing agents. PDE2 inhibitor BAY60-7550 did not show any effect on mice lacking the NP GC-A receptor (NPR-A), but it showed positive effects on 
mice treated with L-NAME (NOS inhibitor). Thus, the positive effect of PDE2 inhibition alone was dependent on intact NP bioactivity, but not on NO-dependent signalling. Accordingly, PDE2 inhibition was demonstrated to show pronounced effects on NP-driven cGMP signalling in PH. In contrast to heart failure with upregulated PDE2 expression [16], PDE2 mRNA and protein expression are reduced in pulmonary artery smooth muscle cells from pulmonary arterial hypertension patients and pulmonary arteries from rats with hypoxia-induced PH [196]. Nevertheless, although this study provides evidence for the therapeutic benefits of PDE2 inhibition in $\mathrm{PH}$, both in vitro and in vivo, the role of PDE2 in the pulmonary function is to be further assessed in order to acquire a deeper insight regarding PDE2-mediated effects in PH-related pathologies.

\section{Clinical Perspectives}

Despite the evident compelling role of PDE2 in various cardiac and vascular disease settings, to our knowledge no clinical trials regarding the use of PDE2 inhibitors in CVDs have been performed. Nevertheless, it is of interest to review ongoing clinical use of PDE2 inhibitors in other diseases. Considering the abundant expression of PDE2 in the brain, the use of selective PDE2 inhibitors has been extensively investigated to promote anxiolytic and antidepressant-like effects $[15,202]$. Additionally, other studies focused to address cognition enhancing effects of PDE2 inhibitors in aged and Alzheimer's disease animal models [203,204]. Despite the promising data in preclinical settings, the use of PDE2 inhibitors is currently not clinically approved. The selective PDE2 inhibitor PF-05180999 was originally developed by Pfizer for treatment of cognitive deficits associated with schizophrenia. Thereafter, PF-05180999 was tested in Phase I clinical trials for the treatment of migraines. However, the trials were terminated prematurely due to safety concerns $[15,205]$. Another selective PDE2 inhibitor, TAK-915, was inspected in Phase I trials to determine appropriate dose selection for cognitive impairment therapies in schizophrenia $[15,206,207]$. Beyond the brain, PDE2 was shown to be upregulated in cancerous cells. Therefore, the PDE2A/PDE5A inhibitor exisulind has been evaluated in several clinical trials as it promotes precancerous/cancerous cells apoptosis. Nevertheless, the FDA also disapproved the use of exisulind due to deficiencies in safety and efficacy $[15,208]$. Thereby, the development of safe and potent PDE2 inhibitors remains challenging at the current stage and is to be further investigated in the future.

\section{Conclusions}

In conclusion, studies in CVD models revealed both beneficial and detrimental effects of PDE2 activity. The controversial PDE2 effects seem not only to be dependent on the activity of PDE2 in distinct cardiac cell types, but also in different subcellular compartments. While the enhanced PDE2 activity in one specific subcellular compartment seems to be beneficial, detrimental responses in other microdomains may be disposed. This highlights the degree of complexity but yet indispensable function of cardiac PDE2 compartmentalization. Maintenance of physiological PDE distribution is thereby elemental for the proper function of the myocardium.

Nevertheless, currently both, the activation and inhibition of PDE2, provide solid beneficial outcomes in cardiac pathological disease settings. Further investigations should aim to provide conclusive pharmacological effects upon modulating PDE2 activity in vivo. In addition, a more comprehensive understanding of the role of distinct PDE2 splice variants is required. Development of specific PDE2 agonists and generation of cell type-restricted PDE2 deficient animal models could further elucidate physiological as well as pathophysiological roles of PDE2. Implementing the use of such novel tools will therefore provide evidence to whether PDE2 activity is beneficial or detrimental in cardiovascular diseases.

Author Contributions: M.S.S. and E.C. drafted and designed this article. S.K. and A.E.-A. substantially revised the manuscript. All authors contributed in collection and interpretation of data, and editing the manuscript. All authors have read and agreed to the published version of the manuscript. 
Funding: This work was supported by the German Research Foundation (DFG) grants EL 270/7-3, Transregio-SFB CRC/TRR 205 to A.E.-A. (2017), grant KA 4194/3-3 to S.K. (2020), project no. 288034826-international research training group (IRTG) 2251 to A.E.-A. and S.K., and by research stipend of the German heart Foundation/German Foundation of Heart Research F/45/19 to S.K (2020).

Conflicts of Interest: The authors declare that they have no conflict of interest.

\section{Abbreviations}

$\begin{array}{ll}\text { AC } & \text { Adenylyl cyclase } \\ \text { AhR } & \text { Aryl hydrocarbon receptor } \\ \text { ANP } & \text { Atrial natriuretic peptide } \\ \text { AKAP } & \text { A-kinase anchoring protein } \\ \beta \text {-AR } & \beta \text {-adrenoceptor } \\ \text { BNP } & \text { Brain natriuretic peptide } \\ \text { cAMP } & 3^{\prime}, 5^{\prime} \text {-cyclic adenosine monophosphate } \\ \text { cGMP } & 3^{\prime}, 5^{\prime} \text {-cyclic guanosine monophosphate } \\ \text { CNGCs } & \text { Cyclic nucleotide gated ion channels } \\ \text { CNP } & \text { C-type natriuretic peptide } \\ \text { CVD } & \text { Cardiovascular disease } \\ \text { DRP1 } & \text { Dynamin related protein } 1 \\ \text { ECC } & \text { Excitation-contraction coupling } \\ \text { EPAC } & \text { Exchange proteins directly activated by cAMP } \\ \text { GPCR } & \text { G protein coupled receptors } \\ \text { HUVEC } & \text { Human umbilical vein cells } \\ \text { LTCC } & \text { L-type Ca }{ }^{2+} \text { channel } \\ \text { MI } & \text { Myocardial infarction } \\ \text { MPT } & \text { Mitochondrial permeability transition } \\ \text { MYBPC } & \text { Myosin-binding protein C } \\ \text { NP } & \text { Natriuretic peptide } \\ \text { NOS } & \text { Nitric oxide synthase } \\ \text { PDE } & \text { Phosphodiesterase } \\ \text { pGC } & \text { Particulate guanylyl cyclases } \\ \text { PH } & \text { Pulmonary hypertension } \\ \text { PLB } & \text { Phospholamban } \\ \text { POPDC } & \text { Popeye-domain-containing proteins } \\ \text { RyR } & \text { Ryanodine receptors } \\ \text { sAC } & \text { Soluble adenylyl cyclases } \\ \text { sGC } & \text { Soluble guanylyl cyclases } \\ \text { SNP } & \text { Sodium nitroprusside } \\ \text { SR } & \text { Sarcoplasmic reticulum } \\ \text { TNF- } \alpha & \text { Tumor necrosis factor- } \alpha \\ \text { VEGF } & \text { Vascular endothelial growth factor } \\ \text { VSMC } & \text { Vascular smooth muscle cell } \\ \text { VEC } & \text { Vascular endothelial cell } \\ & \end{array}$

\section{References}

1. Kaptoge, S.; Pennells, L.; De Bacquer, D.; Cooney, M.T.; Kavousi, M.; Stevens, G.; Riley, L.M.; Savin, S.; Khan, T.; Altay, S.; et al. World Health Organization cardiovascular disease risk charts: Revised models to estimate risk in 21 global regions. Lancet Glob. Health 2019, 7, 1332-1345. [CrossRef]

2. Roth, G.A.; Abate, D.; Abate, K.H.; Abay, S.M.; Abbafati, C.; Abbasi, N.; Abbastabar, H.; Abd-Allah, F.; Abdela, J.; Abdelalim, A.; et al. Global, regional, and national age-sex-specific mortality for 282 causes of death in 195 countries and territories, 1980-2017: A systematic analysis for the Global Burden of Disease Study 2017. Lancet 2018, 392, 1736-1788. [CrossRef] 
3. Nelson, S.; Whitsel, L.; Khavjou, O.; Phelps, D.; Leib, A. Projections of Cardiovascular Disease Prevalence and Costs: 2015-2035; Technical Report for American Heart Association: Washington, DC, USA, 2016.

4. Flora, G.D.; Nayak, M.K. A Brief Review of Cardiovascular Diseases, Associated Risk Factors and Current Treatment Regimes. Curr. Pharm. Des. 2019, 25, 4063-4084. [CrossRef] [PubMed]

5. Tzoulaki, I.; Elliott, P.; Kontis, V.; Ezzati, M. Worldwide Exposures to Cardiovascular Risk Factors and Associated Health Effects: Current Knowledge and Data Gaps. Circulation 2016, 133, 2314-2333. [CrossRef] [PubMed]

6. Viacheslav, N.; Manuela, Z. (Eds.) Microdomains in the Cardiovascular System; Springer: Cham, Switzerland, 2017. [CrossRef]

7. Perera, R.K.; Sprenger, J.U.; Steinbrecher, J.H.; Hübscher, D.; Lehnart, S.E.; Abesser, M.; Schuh, K.; El-Armouche, A.; Nikolaev, V.O. Microdomain switch of cGMP-regulated phosphodiesterases leads to ANP-induced augmentation of $\beta$-adrenoceptor-stimulated contractility in early cardiac hypertrophy. Circ. Res. 2015, 116, 1304-1311. [CrossRef] [PubMed]

8. Nikolaev, V.O.; Moshkov, A.; Lyon, A.R.; Miragoli, M.; Novak, P.; Paur, H.; Lohse, M.J.; Korchev, Y.E.; Harding, S.E.; Gorelik, J. $\beta 2$-adrenergic receptor redistribution in heart failure changes cAMP compartmentation. Science 2010, 327, 1653-1657. [CrossRef]

9. Zakhary, D.R.; Moravec, C.S.; Bond, M. Regulation of PKA binding to AKAPs in the heart: Alterations in human heart failure-Alterations in Human Heart Failure. Circulation 2000, 101, 1459-1464. [CrossRef]

10. Mongillo, M.; McSorley, T.; Evellin, S.; Sood, A.; Lissandron, V.; Terrin, A.; Huston, E.; Hannawacker, A.; Lohse, M.J.; Pozzan, T.; et al. Fluorescence resonance energy transfer-based analysis of cAMP dynamics in live neonatal rat cardiac myocytes reveals distinct functions of compartmentalized phosphodiesterases. Circ. Res. 2004, 95, 67-75. [CrossRef]

11. Surdo, N.C.; Berrera, M.; Koschinski, A.; Brescia, M.; MacHado, M.R.; Carr, C.; Wright, P.; Gorelik, J.; Morotti, S.; Grandi, E.; et al. FRET biosensor uncovers cAMP nano-domains at b-adrenergic targets that dictate precise tuning of cardiac contractility. Nat. Commun. 2017, 8, 1-14. [CrossRef]

12. Berisha, F.; Nikolaev, V.O. Cyclic nucleotide imaging and cardiovascular disease. Pharmacol. Ther. 2017, 175, 107-115. [CrossRef]

13. Bedioune, I.; Bobin, P.; Leroy, J.; Fischmeister, R.; Vandecasteele, G. Cyclic Nucleotide Phosphodiesterases and Compartmentation in Normal and Diseased Heart. In Microdomains in the Cardiovascular System; Viacheslav, N., Manuela, Z., Eds.; Springer: Cham, Switzerland, 2017; pp. 97-116.

14. Kim, G.E.; Kass, D.A. Cardiac phosphodiesterases and their modulation for treating heart disease. In Heart Failure; Springer: Cham, Switzerland, 2016; Volume 243, pp. 249-269.

15. Baillie, G.S.; Tejeda, G.S.; Kelly, M.P. Therapeutic targeting of $3^{\prime}, 5^{\prime}$-cyclic nucleotide phosphodiesterases: Inhibition and beyond. Nat. Rev. Drug Discov. 2019, 18, 770-796. [CrossRef] [PubMed]

16. Mehel, H.; Emons, J.; Vettel, C.; Wittköpper, K.; Seppelt, D.; Dewenter, M.; Lutz, S.; Sossalla, S.; Maier, L.S.; Lechêne, P.; et al. Phosphodiesterase-2 is up-regulated in human failing hearts and blunts $\beta$-adrenergic responses in cardiomyocytes. J. Am. Coll. Cardiol. 2013, 62, 1596-1606. [CrossRef] [PubMed]

17. Vettel, C.; Lindner, M.; Dewenter, M.; Lorenz, K.; Schanbacher, C.; Riedel, M.; Lämmle, S.; Meinecke, S.; Mason, F.E.; Sossalla, S.; et al. Phosphodiesterase 2 Protects Against Catecholamine-Induced Arrhythmia and Preserves Contractile Function after Myocardial Infarction. Circ. Res. 2017, 120, 120-132. [CrossRef] [PubMed]

18. Zoccarato, A.; Surdo, N.C.; Aronsen, J.M.; Fields, L.A.; Mancuso, L.; Dodoni, G.; Stangherlin, A.; Livie, C.; Jiang, H.; Sin, Y.Y.; et al. Cardiac hypertrophy is inhibited by a local pool of cAMP regulated by phosphodiesterase 2. Circ. Res. 2015, 117, 707-719. [CrossRef]

19. Baliga, R.S.; Preedy, M.E.J.; Dukinfield, M.S.; Chu, S.M.; Aubdool, A.A.; Bubb, K.J.; Moyes, A.J.; Tones, M.A.; Hobbs, A.J. Phosphodiesterase 2 inhibition preferentially promotes NO/guanylyl cyclase/cGMP signaling to reverse the development of heart failure. Proc. Natl. Acad. Sci. USA 2018, 115, 7428-7437. [CrossRef]

20. Judina, A.; Gorelik, J.; Wright, P.T. Studying signal compartmentation in adult cardiomyocytes. Biochem. Soc. Trans. 2020, 48, 61-70. [CrossRef]

21. Madamanchi, A. $\beta$-adrenergic receptor signaling in cardiac function and heart failure. McGill J. Med. 2007, 10, 99-104. 
22. Keely, S.L. Prostaglandin E1 Activation of Heart cAMP-dependent Protein Kinase: Apparent Dissociation of Protein Kinase Activation from Increases in Phosphorylase Activity and Contractile Force. Mol. Pharmacol. 1979, 15, 235-245.

23. Honda, A.; Sekiguchi, Y.; Mori, Y. Prostaglandin E2 stimulates cyclic AMP-mediated hyaluronan synthesis in rabbit pericardial mesothelial cells. Biochem. J. 1993, 292, 497-502. [CrossRef]

24. Méry, P.F.; Brechler, V.; Pavoine, C.; Pecker, F.; Fischmeister, R. Glucagon stimulates the cardiac $\mathrm{Ca}^{2+}$ current $^{2}$ by activation of adenylyl cyclase and inhibition of phosphodiesterase. Nature 1990, 345, 158-161. [CrossRef]

25. Vila Petroff, M.G.; Egan, J.M.; Wang, X.; Sollott, S.J. Glucagon-Like Peptide-1 Increases cAMP but Fails to Augment Contraction in Adult Rat Cardiac Myocytes. Circ. Res. 2001, 89, 445-452. [CrossRef] [PubMed]

26. Dessauer, C.W.; Watts, V.J.; Ostrom, R.S.; Conti, M.; Dove, S.; Seifert, R. International union of basic and clinical pharmacology. CI. structures and small molecule modulators of mammalian adenylyl cyclases. Pharmacol. Rev. 2017, 69, 96-139. [CrossRef] [PubMed]

27. Birnbaumer, L.; Abramowitz, J.; Brown, A.M. Receptor-effector coupling by G proteins. Biochim. Biophys. Acta 1990, 1031, 163-224. [CrossRef]

28. Tilley, D.G. G protein-dependent and G protein-independent signaling pathways and their impact on cardiac function. Circ. Res. 2011, 109, 217-230. [CrossRef]

29. Schirmer, I.; Bualeong, T.; Budde, H.; Cimiotti, D.; Appukuttan, A.; Klein, N.; Steinwascher, P.; Reusch, P.; Mügge, A.; Meyer, R.; et al. Soluble adenylyl cyclase: A novel player in cardiac hypertrophy induced by isoprenaline or pressure overload. PLoS ONE 2018, 13, e0192322. [CrossRef]

30. Boularan, C.; Gales, C. Cardiac cAMP: Production, hydrolysis, modulation and detection. Front. Pharmacol. 2015, 6, 203. [CrossRef]

31. Nakano, S.J.; Sucharov, J.; van Dusen, R.; Cecil, M.; Nunley, K.; Wickers, S.; Karimpur-Fard, A.; Stauffer, B.L.; Miyamoto, S.D.; Sucharov, C.C. Cardiac Adenylyl Cyclase and Phosphodiesterase Expression Profiles Vary by Age, Disease, and Chronic Phosphodiesterase Inhibitor Treatment. J. Card. Fail. 2017, 23, 72-80. [CrossRef]

32. Baldwin, T.A.; Dessauer, C.W. Function of Adenylyl Cyclase in Heart: The AKAP Connection. J. Cardiovasc. Dev. Dis. 2018, 5, 2. [CrossRef]

33. Bers, D.M. Cardiac excitation-contraction coupling. Nature 2002, 415, 198-205. [CrossRef]

34. Bers, D.M. Calcium Cycling and Signaling in Cardiac Myocytes. Annu. Rev. Physiol. 2007, 70, $23-49$. [CrossRef]

35. Indolfi, C.; Avvedimento, E.V.; Di Lorenzo, E.; Esposito, G.; Rapacciuolo, A.; Giuliano, P.; Grieco, D.; Cavuto, L.; Stingone, A.M.; Ciullo, I.; et al. Activation of cAMP-PKA signaling in vivo inhibits smooth muscle cell proliferation induced by vascular injury. Nat. Med. 1997, 3, 775-781. [CrossRef] [PubMed]

36. Morgado, M.; Cairrão, E.; Santos-Silva, A.J.; Verde, I. Cyclic nucleotide-dependent relaxation pathways in vascular smooth muscle. Cell. Mol. Life Sci. 2012, 69, 247-266. [CrossRef] [PubMed]

37. Patterson, C.E.; Lum, H.; Schaphorst, K.L.; Verin, A.D.; Garcia, J.G.N. Regulation of endothelial barrier function by the cAMP-dependent protein kinase. Endothelium 2000, 7, 287-308. [CrossRef] [PubMed]

38. Moss, R.L.; Fitzsimons, D.P.; Ralphe, J.C. Cardiac MyBP-C Regulates the Rate and Force of Contraction in Mammalian Myocardium. Circ. Res. 2015, 116, 183-192. [CrossRef] [PubMed]

39. Li, L.; Desantiago, J.; Chu, G.; Kranias, E.G.; Bers, D.M. Phosphorylation of phospholamban and troponin I in $\beta$-adrenergic-induced acceleration of cardiac relaxation. Am. J. Physiol. Heart Circ. Physiol. 2000, 278, 69-79. [CrossRef]

40. El-Armouche, A.; Eschenhagen, T. $\beta$-Adrenergic stimulation and myocardial function in the failing heart. Heart Fail. Rev. 2009, 14, 225-241. [CrossRef]

41. Saucerman, J.J.; McCulloch, A.D. Cardiac beta-Adrenergic Signaling: From Subcellular Microdomains to Heart Failure. Ann. N. Y. Acad. Sci. 2006, 1080, 348-361. [CrossRef]

42. Yang, J.H.; Polanowska-Grabowska, R.K.; Smith, J.S.; Shields, C.W.; Saucerman, J.J. PKA catalytic subunit compartmentation regulates contractile and hypertrophic responses to $\beta$-adrenergic signaling. J. Mol. Cell. Cardiol. 2014, 66, 83-93. [CrossRef]

43. Tomita, H.; Nazmy, M.; Kajimoto, K.; Yehia, G.; Molina, C.A.; Sadoshima, J. Inducible cAMP early repressor (ICER) is a negative-feedback regulator of cardiac hypertrophy and an important mediator of cardiac myocyte apoptosis in response to $\beta$-adrenergic receptor stimulation. Circ. Res. 2003, 93, 12-22. [CrossRef]

44. Roberts, O.L.; Dart, C. CAMP signalling in the vasculature: The role of Epac (exchange protein directly activated by cAMP). Biochem. Soc. Trans. 2014, 42, 89-97. [CrossRef] 
45. Fujita, T.; Umemura, M.; Yokoyama, U.; Okumura, S.; Ishikawa, Y. The role of Epac in the heart. Cell. Mol. Life Sci. 2017, 74, 591-606. [CrossRef] [PubMed]

46. Bucchi, A.; Piantoni, C.; Barbuti, A.; DiFrancesco, D.; Baruscotti, M. HCN Channels and Cardiac Pacemaking. In Channelopathies in Heart Disease; Thomas, D., Remme, C.A., Eds.; Springer: Cham, Switzerland, 2018; pp. 97-126.

47. Shen, B.; Cheng, K.T.; Leung, Y.K.; Kwok, Y.C.; Kwan, H.Y.; Wong, C.O.; Chen, Z.Y.; Huang, Y.; Yao, X. Epinephrine-induced $\mathrm{Ca}^{2+}$ influx in vascular endothelial cells is mediated by CNGA2 channels. J. Mol. Cell. Cardiol. 2008, 45, 437-445. [CrossRef] [PubMed]

48. Leung, Y.K.; Du, J.; Huang, Y.; Yao, X. Cyclic Nucleotide-Gated Channels Contribute to Thromboxane A2-Induced Contraction of Rat Small Mesenteric Arteries. PLoS ONE 2010, 5, e11098. [CrossRef] [PubMed]

49. Froese, A.; Breher, S.S.; Waldeyer, C.; Schindler, R.F.R.; Nikolaev, V.O.; Rinné, S.; Wischmeyer, E.; Schlueter, J.; Becher, J.; Simrick, S.; et al. Popeye domain containing proteins are essential for stress-mediated modulation of cardiac pacemaking in mice. J. Clin. Investig. 2012, 122, 1119-1130. [CrossRef] [PubMed]

50. Brand, T. POPDC proteins and cardiac function. Biochem. Soc. Trans. 2019, 47, 1393-1404. [CrossRef]

51. Schindler, R.; Scotton, C.; French, V.; Ferlini, A.; Brand, T. The Popeye Domain Containing Genes and Their Function in Striated Muscle. J. Cardiovasc. Dev. Dis. 2016, 3, 22. [CrossRef]

52. Park, M.; Sandner, P.; Krieg, T. cGMP at the centre of attention: Emerging strategies for activating the cardioprotective PKG pathway. Basic Res. Cardiol. 2018, 113, 1-7. [CrossRef]

53. Potter, L.R. Guanylyl cyclase structure, function and regulation. Cell. Signal. 2011, 23, 1921-1926. [CrossRef]

54. Potter, L.R. Regulation and therapeutic targeting of peptide-activated receptor guanylyl cyclases. Pharmacol. Ther. 2011, 130, 71-82. [CrossRef]

55. Denninger, J.W.; Marletta, M.A. Guanylate cyclase and the .NO/cGMP signaling pathway. Biochim. Biophys. Acta 1999, 1411, 334-350. [CrossRef]

56. Russwurm, M.; Behrends, S.; Harteneck, C.; Koesling, D. Functional properties of a naturally occurring isoform of soluble guanylyl cyclase. Biochem. J. 1998, 335, 125-130. [CrossRef] [PubMed]

57. Mergia, E.; Stegbauer, J. Role of Phosphodiesterase 5 and Cyclic GMP in Hypertension. Curr. Hypertens. Rep. 2016, 18, 1-8. [CrossRef] [PubMed]

58. Kuhn, M. Molecular physiology of membrane guanylyl cyclase receptors. Physiol. Rev. 2016, 96, 751-804. [CrossRef]

59. Matsuo, A.; Nagai-Okatani, C.; Nishigori, M.; Kangawa, K.; Minamino, N. Natriuretic peptides in human heart: Novel insight into their molecular forms, functions, and diagnostic use. Peptides 2019, 111, 3-17. [CrossRef] [PubMed]

60. Minamino, N.; Horio, T.; Nishikimi, T. Natriuretic Peptides in the Cardiovascular System. In Handbook of Biologically Active Peptides; Kastin, A.J., Ed.; Academic Press: Burlington, MA, USA, 2006; pp. 1199-1207.

61. Stangherlin, A.; Gesellchen, F.; Zoccarato, A.; Terrin, A.; Fields, L.A.; Berrera, M.; Surdo, N.C.; Craig, M.A.; Smith, G.; Hamilton, G.; et al. CGMP signals modulate camp levels in a compartment-specific manner to regulate catecholamine-dependent signaling in cardiac myocytes. Circ. Res. 2011, 108, 929-939. [CrossRef]

62. Cuello, F.; Nikolaev, V.O. Cardiac cGMP Signaling in Health and Disease. J. Cardiovasc. Pharmacol. 2020, 75, 399-409. [CrossRef]

63. Blanton, R.M. cGMP Signaling and Modulation in Heart Failure. J. Cardiovasc. Pharmacol. 2020, 75, 385-398. [CrossRef]

64. Tsai, E.J.; Kass, D.A. Cyclic GMP signaling in cardiovascular pathophysiology and therapeutics. Pharmacol. Ther. 2009, 122, 216-238. [CrossRef]

65. Krüger, M.; Kötter, S.; Grützner, A.; Lang, P.; Andresen, C.; Redfield, M.M.; Butt, E.; dos Remedios, C.G.; Linke, W.A. Protein kinase $\mathrm{G}$ modulates human myocardial passive stiffness by phosphorylation of the titin springs. Circ. Res. 2009, 104, 87-94. [CrossRef]

66. Fiedler, B.; Lohmann, S.M.; Smolenski, A.; Linnemüller, S.; Pieske, B.; Schröder, F.; Molkentin, J.D.; Drexler, H.; Wollert, K.C. Inhibition of calcineurin-NFAT hypertrophy signaling by cGMP-dependent protein kinase type I in cardiac myocytes. Proc. Natl. Acad. Sci. USA 2002, 99, 11363-11368. [CrossRef]

67. Kinoshita, H.; Kuwahara, K.; Nishida, M.; Jian, Z.; Rong, X.; Kiyonaka, S.; Kuwabara, Y.; Kurose, H.; Inoue, R.; Mori, Y.; et al. Inhibition of TRPC6 channel activity contributes to the antihypertrophic effects of natriuretic peptides-guanylyl cyclase-a signaling in the heart. Circ. Res. 2010, 106, 1849-1860. [CrossRef] [PubMed] 
68. Klaiber, M.; Kruse, M.; Völker, K.; Schröter, J.; Feil, R.; Freichel, M.; Gerling, A.; Feil, S.; Dietrich, A.; Londoño, J.E.C.; et al. Novel insights into the mechanisms mediating the local antihypertrophic effects of cardiac atrial natriuretic peptide: Role of cGMP-dependent protein kinase and RGS2. Basic Res. Cardiol. 2010, 105, 583-595. [CrossRef] [PubMed]

69. Tokudome, T.; Kishimoto, I.; Horio, T.; Arai, Y.; Schwenke, D.O.; Hino, J.; Okano, I.; Kawano, Y.; Kohno, M.; Miyazato, M.; et al. Regulator of G-protein signaling subtype 4 mediates antihypertrophic effect of locally secreted natriuretic peptides in the heart. Circulation 2008, 117, 2329-2339. [CrossRef] [PubMed]

70. Kukreja, R.C.; Salloum, F.N.; Das, A.; Koka, S.; Ockaili, R.A.; Xi, L. Emerging new uses of phosphodiesterase-5 inhibitors in cardiovascular diseases. Exp. Clin. Cardiol. 2011, 16, e30. [PubMed]

71. Kitakaze, M.; Asakura, M.; Kim, J.; Shintani, Y.; Asanuma, H.; Hamasaki, T.; Seguchi, O.; Myoishi, M.; Minamino, T.; Ohara, T.; et al. Human atrial natriuretic peptide and nicorandil as adjuncts to reperfusion treatment for acute myocardial infarction (J-WIND): Two randomised trials. Lancet 2007, 370, 1483-1493. [CrossRef]

72. Madhani, M.; Hall, A.R.; Cuello, F.; Charles, R.L.; Burgoyne, J.R.; Fuller, W.; Hobbs, A.J.; Shattock, M.J.; Eaton, P. Phospholemman Ser69 phosphorylation contributes to sildenafil-induced cardioprotection against reperfusion injury. Am. J. Physiol. Circ. Physiol. 2010, 299, H827-H836. [CrossRef]

73. Costa, A.D.T.; Garlid, K.D.; West, I.C.; Lincoln, T.M.; Downey, J.M.; Cohen, M.V.; Critz, S.D. Protein kinase G transmits the cardioprotective signal from cytosol to mitochondria. Circ. Res. 2005, 97, 329-336. [CrossRef]

74. Das, A.; Xi, L.; Kukreja, R.C. Protein kinase G-dependent cardioprotective mechanism of phosphodiesterase-5 inhibition involves phosphorylation of ERK and GSK3ß. J. Biol. Chem. 2008, 283, 29572-29585. [CrossRef]

75. Costa, A.D.T.; Pierre, S.V.; Cohen, M.V.; Downey, J.M.; Garlid, K.D. cGMP signalling in pre-and post-conditioning: The role of mitochondria. Cardiovasc. Res. 2008, 77, 344-352. [CrossRef]

76. Kass, D.A.; Takimoto, E.; Nagayama, T.; Champion, H.C. Phosphodiesterase regulation of nitric oxide signaling. Cardiovasc. Res. 2007, 75, 303-314. [CrossRef]

77. VanSchouwen, B.; Melacini, G. Regulation of $\mathrm{HCN}$ ion channels by non-canonical cyclic nucleotides. Handb. Exp. Pharmacol. 2017, 238, 123-133. [PubMed]

78. Zhao, C.Y.; Greenstein, J.L.; Winslow, R.L. Roles of phosphodiesterases in the regulation of the cardiac cyclic nucleotide cross-talk signaling network. J. Mol. Cell. Cardiol. 2016, 91, 215-227. [CrossRef] [PubMed]

79. Hayes, J.S.; Brunton, L.L.; Brown, J.H.; Reese, J.B.; Mayer, S.E. Hormonally specific expression of cardiac protein kinase activity. Proc. Natl. Acad. Sci. USA 1979, 76, 1570-1574. [CrossRef] [PubMed]

80. Zoccarato, A.; Zaccolo, M. cAMP Compartmentalisation and Hypertrophy of the Heart: 'Good' Pools of cAMP and 'Bad' Pools of cAMP Coexist in the Same Cardiac Myocyte. In Microdomains in the Cardiovascular System; Nikolaev, V., Zaccolo, M., Eds.; Springer: Cham, Switzerland, 2017; pp. 117-141.

81. Perera, R.K.; Nikolaev, V.O. Compartmentation of cAMP signalling in cardiomyocytes in health and disease. Acta Physiol. 2013, 207, 650-662. [CrossRef]

82. Bhogal, N.; Hasan, A.; Gorelik, J. The Development of Compartmentation of cAMP Signaling in Cardiomyocytes: The Role of T-Tubules and Caveolae Microdomains. J. Cardiovasc. Dev. Dis. 2018, 5, 25. [CrossRef]

83. Agarwal, S.R.; Gratwohl, J.; Cozad, M.; Yang, P.-C.; Clancy, C.E.; Harvey, R.D. Compartmentalized cAMP Signaling Associated With Lipid Raft and Non-raft Membrane Domains in Adult Ventricular Myocytes. Front. Pharmacol. 2018, 9, 332. [CrossRef]

84. Schobesberger, S.; Wright, P.T.; Poulet, C.; Sanchez-Alonso, J.L.; Mansfield, C.; Friebe, A.; Harding, S.E.; Balligand, J.L.; Nikolaev, V.O.; Gorelik, J. $\beta 3$-Adrenoceptor redistribution impairs NO/cGMP/PDE2 signalling in failing cardiomyocytes. Elife 2020, 9, e52221. [CrossRef]

85. Johnstone, T.B.; Agarwal, S.R.; Harvey, R.D.; Ostrom, R.S. cAMP Signaling Compartmentation: Adenylyl Cyclases as Anchors of Dynamic Signaling Complexes. Mol. Pharmacol. 2018, 93, 270-276. [CrossRef]

86. Rybin, V.O.; Pak, E.; Alcott, S.; Steinberg, S.F. Developmental changes in $\beta 2$-adrenergic receptor signaling in ventricular myocytes: The role of Gi proteins and caveolae microdomains. Mol. Pharmacol. 2003, 63, 1338-1348. [CrossRef]

87. Head, B.P.; Pateli, H.H.; Roth, D.M.; Lai, N.C.; Niesman, I.R.; Farquhar, M.G.; Insel, P.A. G-protein-coupled receptor signaling components localize in both sarcolemmal and intracellular caveolin-3-associated microdomains in adult cardiac myocytes. J. Biol. Chem. 2005, 280, 31036-31044. [CrossRef] 
88. Calaghan, S.; White, E. Caveolae modulate excitation-contraction coupling and $\beta 2$ - adrenergic signalling in adult rat ventricular myocytes. Cardiovasc. Res. 2006, 69, 816-824. [CrossRef] [PubMed]

89. Agarwal, S.R.; MacDougall, D.A.; Tyser, R.; Pugh, S.D.; Calaghan, S.C.; Harvey, R.D. Effects of cholesterol depletion on compartmentalized cAMP responses in adult cardiac myocytes. J. Mol. Cell. Cardiol. 2011, 50, 500-509. [CrossRef] [PubMed]

90. Drab, M.; Verkade, P.; Elger, M.; Kasper, M.; Lohn, M.; Lauterbach, B.; Menne, J.; Lindschau, C.; Mende, F.; Luft, F.C.; et al. Loss of caveolae, vascular dysfunction, and pulmonary defects in caveolin-1 gene-disrupted mice. Science 2001, 293, 2449-2452. [CrossRef] [PubMed]

91. Razani, B.; Engelman, J.A.; Wang, X.B.; Schubert, W.; Zhang, X.L.; Marks, C.B.; Macalusol, F.; Russell, R.G.; Li, M.; Pestell, R.G.; et al. Caveolin-1 Null Mice Are Viable but Show Evidence of Hyperproliferative and Vascular Abnormalities. J. Biol. Chem. 2001, 276, 38121-38138. [CrossRef]

92. Sampson, L.J.; Hayabuchi, Y.; Standen, N.B.; Dart, C. Caveolae localize protein kinase A signaling to arterial ATP-sensitive potassium channels. Circ. Res. 2004, 95, 1012-1018. [CrossRef]

93. Redden, J.M.; Dodge-Kafka, K.L.; Kapiloff, M.S. Function to Failure: Compartmentalization of Cardiomyocyte Signaling by A-Kinase-Anchoring Proteins. In Microdomains in the Cardiovascular System; Nikolaev, V., Zaccolo, M., Eds.; Springer: Cham, Switzerland, 2017; pp. 37-57.

94. Zhu, Y.; Jiang, X.; Zheng, Y.; Xiong, J.; Wei, D.; Zhang, D. Cardiac function modulation depends on the A-kinase anchoring protein complex. J. Cell. Mol. Med. 2019, 23, 7170-7179. [CrossRef]

95. Diviani, D.; Osman, H.; Reggi, E. A-Kinase Anchoring Protein-Lbc: A Molecular Scaffold Involved in Cardiac Protection. J. Cardiovasc. Dev. Dis. 2018, 5, 12. [CrossRef]

96. Diviani, D.; Reggi, E.; Arambasic, M.; Caso, S.; Maric, D. Emerging roles of A-kinase anchoring proteins in cardiovascular pathophysiology. Biochim. Biophys. Acta 2016, 1863, 1926-1936. [CrossRef]

97. Kritzer, M.D.; Li, J.; Dodge-Kafka, K.; Kapiloff, M.S. AKAPs: The architectural underpinnings of local cAMP signaling. J. Mol. Cell. Cardiol. 2012, 52, 351-358. [CrossRef]

98. Efendiev, R.; Samelson, B.K.; Nguyen, B.T.; Phatarpekar, P.V.; Baameur, F.; Scott, J.D.; Dessauer, C.W. AKAP79 interacts with multiple Adenylyl Cyclase (AC) isoforms and scaffolds AC5 and -6 to $\alpha$-amino-3-hydroxyl-5-methyl-4-isoxazole-propionate (AMPA) receptors. J. Biol. Chem. 2010, 285, 14450-14458. [CrossRef]

99. Shen, J.X.; Cooper, D.M.F. AKAP79, PKC, PKA and PDE4 participate in a Gq-linked muscarinic receptor and adenylate cyclase 2 cAMP signalling complex. Biochem. J. 2013, 455, 47-56. [CrossRef] [PubMed]

100. Delint-Ramirez, I.; Willoughby, D.; Hammond, G.V.R.; Ayling, L.J.; Cooper, D.M.F. Palmitoylation targets AKAP79 protein to lipid rafts and promotes its regulation of calcium-sensitive adenylyl cyclase type 8. J. Biol. Chem. 2011, 286, 32962-32975. [CrossRef] [PubMed]

101. Kapiloff, M.S.; Piggott, L.A.; Sadana, R.; Li, J.; Heredia, L.A.; Henson, E.; Efendiev, R.; Dessauer, C.W. An adenylyl cyclase-mAKAP $\beta$ signaling complex regulates cAMP levels in cardiac myocytes. J. Biol. Chem. 2009, 284, 23540-23546. [CrossRef] [PubMed]

102. Lehnart, S.E.; Wehrens, X.H.T.; Reiken, S.; Warrier, S.; Belevych, A.E.; Harvey, R.D.; Richter, W.; Jin, S.L.C.; Conti, M.; Marks, A.R. Phosphodiesterase 4D deficiency in the ryanodine-receptor complex promotes heart failure and arrhythmias. Cell 2005, 123, 25-35. [CrossRef] [PubMed]

103. Dodge, K.L.; Khouangsathiene, S.; Kapiloff, M.S.; Mouton, R.; Hill, E.V.; Houslay, M.D.; Langeberg, L.K.; Scott, J.D. mAKAP assembles a protein kinase A/PDE4 phosphodiesterase cAMP signaling module. EMBO J. 2001, 20, 1921-1930. [CrossRef]

104. Terrenoire, C.; Houslay, M.D.; Baillie, G.S.; Kass, R.S. The cardiac IKs potassium channel macromolecular complex includes the phosphodiesterase PDE4D3. J. Biol. Chem. 2009, 284, 9140-9146. [CrossRef]

105. Indolfi, C.; Stabile, E.; Coppola, C.; Gallo, A.; Perrino, C.; Allevato, G.; Cavuto, L.; Torella, D.; Di Lorenzo, E.; Troncone, G.; et al. Membrane-Bound Protein Kinase A Inhibits Smooth Muscle Cell Proliferation In Vitro and In Vivo by Amplifying cAMP-Protein Kinase A Signals. Circ. Res. 2001, 88, 319-324. [CrossRef]

106. Zhong, J.; Hume, J.R.; Keef, K.D. Anchoring protein is required for cAMP-dependent stimulation of L-type $\mathrm{Ca}^{2+}$ channels in rabbit portal vein. Am. J. Physiol. 1999, 277, C840-C844. [CrossRef]

107. Hayabuchi, Y.; Dart, C.; Standen, N.B. Evidence for involvement of A-kinase anchoring protein in activation of rat arterial KATP channels by protein kinase A. J. Physiol. 2001, 536, 421-427. [CrossRef] 
108. Richards, M.; Lomas, O.; Jalink, K.; Ford, K.L.; Vaughan-Jones, R.D.; Lefkimmiatis, K.; Swietach, P. Intracellular tortuosity underlies slow cAMP diffusion in adult ventricular myocytes. Cardiovasc. Res. 2016, 110, 395-407. [CrossRef]

109. Sassi, Y.; Abi-Gerges, A.; Fauconnier, J.; Mougenot, N.; Reiken, S.; Haghighi, K.; Kranias, E.G.; Marks, A.R.; Lacampagne, A.; Engelhardt, S.; et al. Regulation of cAMP homeostasis by the efflux protein MRP4 in cardiac myocytes. FASEB J. 2012, 26, 1009-1017. [CrossRef] [PubMed]

110. Zaccolo, M.; Movsesian, M.A. cAMP and cGMP signaling cross-talk: Role of phosphodiesterases and implications for cardiac pathophysiology. Circ. Res. 2007, 100, 1569-1578. [CrossRef] [PubMed]

111. Conti, M.; Mika, D.; Richter, W. Cyclic AMP compartments and signaling specificity: Role of cyclic nucleotide phosphodiesterases. J. Gen. Physiol. 2014, 143, 29-38. [CrossRef]

112. Omori, K.; Kotera, J. Overview of PDEs and their regulation. Circ. Res. 2007, 100, 309-327. [CrossRef] [PubMed]

113. Kokkonen, K.; Kass, D.A. Nanodomain Regulation of Cardiac Cyclic Nucleotide Signaling by Phosphodiesterases. Annu. Rev. Pharmacol. Toxicol. 2017, 57, 455-479. [CrossRef] [PubMed]

114. Rybalkin, S.D.; Yan, C.; Bornfeldt, K.E.; Beavo, J.A. Cyclic GMP phosphodiesterases and regulation of smooth muscle function. Circ. Res. 2003, 93, 280-291. [CrossRef]

115. Surapisitchat, J.; Beavo, J.A. Regulation of endothelial barrier function by cyclic nucleotides: The role of phosphodiesterases. Handb. Exp. Pharmacol. 2011, 204, 193-210. [CrossRef]

116. Martins, T.J.; Mumby, M.C.; Beavog, J.A. Purification and Characterization of a Cyclic GMP-stimulated Cyclic Nucleotide Phosphodiesterase from Bovine Tissues. J. Biol. Chem. 1982, 257, 1973-1979.

117. Pandit, J.; Forman, M.D.; Fennell, K.F.; Dillman, K.S.; Menniti, F.S. Mechanism for the allosteric regulation of phosphodiesterase 2A deduced from the X-ray structure of a near full-length construct. Proc. Natl. Acad. Sci. USA 2009, 106, 18225-18230. [CrossRef]

118. Rascón, A.; Soderling, S.H.; Schaefer, J.B.; Beavo, J.A. Cloning and characterization of cAMP-specific phosphodiesterase (TbPDE2B) from Trypanosoma brucei. Proc. Natl. Acad. Sci. USA 2002, 99, 4714-4719. [CrossRef]

119. Rosman, G.J.; Martins, T.J.; Sonnenburg, W.K.; Beavo, J.A.; Ferguson, K.; Loughney, K. Isolation and characterization of human cDNAs encoding a cGMP-stimulated $3^{\prime}, 5^{\prime}$-cyclic nucleotide phosphodiesterase. Gene 1997, 191, 89-95. [CrossRef]

120. Russwurm, C.; Zoidl, G.; Koesling, D.; Russwurm, M. Dual acylation of PDE2A splice variant 3. Targeting to synaptic membranes. J. Biol. Chem. 2009, 284, 25782-25790. [CrossRef] [PubMed]

121. Beavo, J.A.; Francis, S.H.; Houslay, M.D. (Eds.) Cyclic Nucleotide Phosphodiesterases in Health and Disease, 1st ed.; CRC Press: Boca Raton, FL, USA, 2006.

122. Monterisi, S.; Lobo, M.J.; Livie, C.; Castle, J.C.; Weinberger, M.; Baillie, G.; Surdo, N.C.; Musheshe, N.; Stangherlin, A.; Gottlieb, E.; et al. PDE2A2 regulates mitochondria morphology and apoptotic cell death via local modulation of cAMP/PKA signalling. Elife 2017, 6. [CrossRef] [PubMed]

123. Geoffroy, V.; Fouque, F.; Nivet, V.; Clot, J.-P.; Lugnier, C.; Desbuquois, B.; Benelli, C. Activation of a cGMP-stimulated cAMP phosphodiesterase by protein kinase $\mathrm{C}$ in a liver Golgi-endosomal fraction. Eur. J. Biochem. 2001, 259, 892-900. [CrossRef]

124. Mongillo, M.; Tocchetti, C.G.; Terrin, A.; Lissandron, V.; Cheung, Y.F.; Dostmann, W.R.; Pozzan, T.; Kass, D.A.; Paolocci, N.; Houslay, M.D.; et al. Compartmentalized phosphodiesterase-2 activity blunts $\beta$-adrenergic cardiac inotropy via an NO/cGMP-dependent pathway. Circ. Res. 2006, 98, 226-234. [CrossRef]

125. Lugnier, C.; Keravis, T.; Le Bec, A.; Pauvert, O.; Proteau, S.; Rousseau, E. Characterization of cyclic nucleotide phosphodiesterase isoforms associated to isolated cardiac nuclei. Biochim. Biophys. Acta 1999, 1472, 431-446. [CrossRef]

126. Martinez, S.E.; Wu, A.Y.; Glavas, N.A.; Tang, X.B.; Turley, S.; Hol, W.G.J.; Beavo, J.A. The two GAF domains in phosphodiesterase 2A have distinct roles in dimerization and in cGMP binding. Proc. Natl. Acad. Sci. USA 2002, 99, 13260-13265. [CrossRef]

127. Martinez, S.E.; Beavo, J.A.; Hol, W.G.J. GAF domains: Two-billion-year-old molecular switches that bind cyclic nucleotides. Mol. Interv. 2002, 2, 317-323. [CrossRef]

128. Wu, A.Y.; Tang, X.B.; Martinez, S.E.; Ikeda, K.; Beavo, J.A. Molecular determinants for cyclic nucleotide binding to the regulatory domains of phosphodiesterase 2A. J. Biol. Chem. 2004, 279, 37928-37938. [CrossRef] 
129. Zhu, J.; Yang, Q.; Dai, D.; Huang, Q. X-ray crystal structure of phosphodiesterase 2 in complex with a highly selective, nanomolar inhibitor reveals a binding-induced pocket important for selectivity. J. Am. Chem. Soc. 2013, 135, 11708-11711. [CrossRef]

130. Card, G.L.; England, B.P.; Suzuki, Y.; Fong, D.; Powell, B.; Lee, B.; Luu, C.; Tabrizizad, M.; Gillette, S.; Ibrahim, P.N.; et al. Structural basis for the activity of drugs that inhibit phosphodiesterases. Structure 2004, 12, 2233-2247. [CrossRef] [PubMed]

131. Osadchii, O.E. Myocardial Phosphodiesterases and Regulation of Cardiac Contractility in Health and Cardiac Disease. Cardiovasc. Drugs Ther. 2007, 21, 171-194. [CrossRef] [PubMed]

132. Terasaki, W.L.; Appleman, M.M. The role of cyclic GMP in the regulation of cyclic AMP hydrolysis. Metabolism 1975, 24, 311-319. [CrossRef]

133. Weber, S.; Zeller, M.; Guan, K.; Wunder, F.; Wagner, M.; El-Armouche, A. PDE2 at the crossway between cAMP and cGMP signalling in the heart. Cell. Signal. 2017, 38, 76-84. [CrossRef]

134. De Oliveira, S.K.; Hoffmeister, M.; Gambaryan, S.; Müller-Esterl, W.; Guimaraes, J.A.; Smolenski, A.P. Phosphodiesterase 2A forms a complex with the co-chaperone XAP2 and regulates nuclear translocation of the aryl hydrocarbon receptor. J. Biol. Chem. 2007, 282, 13656-13663. [CrossRef]

135. Walker, M.K.; Thackaberry, E.A.; Gabaldon, D.M.; Smith, S.M. Aryl Hydrocarbon Receptor Null Mice Develop Cardiac Hypertrophy and Increased Hypoxia-Inducible Factor-1a in the Absence of Cardiac Hypoxia. Cardiovasc. Toxicol. 2002, 2, 263-273.

136. Mery, P.F.; Pavoine, C.; Belhassen, L.; Pecker, F.; Fischmeister, R. Nitric oxide regulates cardiac Ca ${ }^{2+}$ current. Involvement of cGMP-inhibited and cGMP-stimulated phosphodiesterases through guanylyl cyclase activation. J. Biol. Chem. 1993, 268, 26286-26295. [PubMed]

137. Kim, K.H.; Kim, H.K.; Hwang, I.C.; Cho, H.J.; Je, N.; Kwon, O.M.; Choi, S.J.; Lee, S.P.; Kim, Y.J.; Sohn, D.W. PDE 5 inhibition with udenafil improves left ventricular systolic/diastolic functions and exercise capacity in patients with chronic heart failure with reduced ejection fraction; A 12-week, randomized, double-blind, placebo-controlled trial. Am. Heart J. 2015, 169, 813-822.e3. [CrossRef]

138. Redfield, M.M.; Chen, H.H.; Borlaug, B.A.; Semigran, M.J.; Lee, K.L.; Lewis, G.; LeWinter, M.M.; Rouleau, J.L.; Bull, D.A.; Mann, D.L.; et al. Effect of phosphodiesterase- 5 inhibition on exercise capacity and clinical status in heart failure with preserved ejection fraction: A randomized clinical trial. JAMA 2013, 309, 1268-1277. [CrossRef]

139. Herring, N.; Rigg, L.; Terrar, D.A.; Paterson, D.J. NO-cGMP pathway increases the hyperpolarisation-activated current, If, and heart rate during adrenergic stimulation. Cardiovasc. Res. 2001, 52, 446-453. [CrossRef]

140. Gustafsson, Å.B.; Brunton, L.L. Attenuation of cAMP accumulation in adult rat cardiac fibroblasts by IL-1 $\beta$ and NO: Role of cGMP-stimulated PDE2. Am. J. Physiol. Physiol. 2002, 283, C463-C471. [CrossRef] [PubMed]

141. Rozmaritsa, N.; Christ, T.; Van Wagoner, D.R.; Haase, H.; Stasch, J.-P.; Matschke, K.; Ravens, U. Attenuated response of L-type calcium current to nitric oxide in atrial fibrillation. Cardiovasc. Res. 2014, 101, 533-542. [CrossRef] [PubMed]

142. Román Moltzau, L.; Meier, S.; Magnus Aronsen, J.; Afzal, F.; Sjaastad, I.; Skomedal, T.; Osnes, J.-B.; Olav Levy, F.; Qvigstad, E. Differential regulation of C-type natriuretic peptide-induced cGMP and functional responses by PDE2 and PDE3 in failing myocardium. Naunyn Schmiedebergs Arch. Pharmacol. 2014, 387, 407-417. [CrossRef] [PubMed]

143. Stephenson, D.T.; Coskran, T.M.; Wilhelms, M.B.; Adamowicz, W.O.; O’Donnell, M.M.; Muravnick, K.B.; Menniti, F.S.; Kleiman, R.J.; Morton, D. Immunohistochemical localization of phosphodiesterase 2A in multiple mammalian species. J. Histochem. Cytochem. 2009, 57, 933-949. [CrossRef]

144. Vettel, C.; Lämmle, S.; Ewens, S.; Cervirgen, C.; Emons, J.; Ongherth, A.; Dewenter, M.; Lindner, D.; Westermann, D.; Nikolaev, V.O.; et al. PDE2-mediated cAMP hydrolysis accelerates cardiac fibroblast to myofibroblast conversion and is antagonized by exogenous activation of cGMP signaling pathways. Am. J. Physiol. Circ. Physiol. 2014, 306, H1246-H1252. [CrossRef] [PubMed]

145. Wang, L.; Henrich, M.; Buckler, K.J.; McMenamin, M.; Mee, C.J.; Sattelle, D.B.; Paterson, D.J. Neuronal nitric oxide synthase gene transfer decreases $\left[\mathrm{Ca}^{2+}\right]_{\mathrm{i}}$ in cardiac sympathetic neurons. J. Mol. Cell. Cardiol. 2007, 43, 717-725. [CrossRef] [PubMed]

146. Xu, Y.; Pan, J.; Sun, J.; Ding, L.; Ruan, L.; Reed, M.; Yu, X.; klabnik, J.; Lin, D.; Li, J.; et al. Inhibition of phosphodiesterase 2 reverses impaired cognition and neuronal remodeling caused by chronic stress. Neurobiol. Aging 2015, 36, 955-970. [CrossRef] [PubMed] 
147. Liu, K.; Li, D.; Hao, G.; McCaffary, D.; Neely, O.; Woodward, L.; Ioannides, D.; Lu, C.J.; Brescia, M.; Zaccolo, M.; et al. Phosphodiesterase $2 \mathrm{~A}$ as a therapeutic target to restore cardiac neurotransmission during sympathetic hyperactivity. JCI Insight 2018, 3. [CrossRef]

148. Li, D.; Lu, C.J.; Hao, G.; Wright, H.; Woodward, L.; Liu, K.; Vergari, E.; Surdo, N.C.; Herring, N.; Zaccolo, M.; et al. Efficacy of B-type natriuretic peptide is coupled to phosphodiesterase 2A in cardiac sympathetic neurons. Hypertension 2015, 66, 190-198. [CrossRef]

149. Bender, A.T.; Beavo, J.A. Specific localized expression of cGMP PDEs in Purkinje neurons and macrophages. Neurochem. Int. 2004, 45, 853-857. [CrossRef]

150. Bender, A.T.; Ostenson, C.L.; Giordano, D.; Beavo, J.A. Differentiation of human monocytes in vitro with granulocyte-macrophage colony-stimulating factor and macrophage colony-stimulating factor produces distinct changes in cGMP phosphodiesterase expression. Cell. Signal. 2004, 16, 365-374. [CrossRef] [PubMed]

151. Michie, A.M.; Lobban, M.; Müller, T.; Harnett, M.M.; Houslay, M.D. Rapid regulation of PDE-2 and PDE-4 cyclic AMP phosphodiesterase activity following ligation of the $\mathrm{T}$ cell antigen receptor on thymocytes: Analysis using the selective inhibitors erythro-9-(2-hydroxy-3-nonyl)-adenine (EHNA) and rolipram. Cell. Signal. 1996, 8, 97-110. [CrossRef]

152. Witwicka, H.; Kobiałka, M.; Siednienko, J.; Mitkiewicz, M.; Gorczyca, W.A. Expression and activity of cGMP-dependent phosphodiesterases is up-regulated by lipopolysaccharide (LPS) in rat peritoneal macrophages. Biochim. Biophys. Acta 2007, 1773, 209-218. [CrossRef] [PubMed]

153. Seybold, J.; Thomas, D.; Witzenrath, M.; Boral, Ş.; Hocke, A.C.; Bürger, A.; Hatzelmann, A.; Tenor, H.; Schudt, C.; Krüll, M.; et al. Tumor necrosis factor- $\alpha$-dependent expression of phosphodiesterase 2: Role in endothelial hyperpermeability. Blood 2005, 105, 3569-3576. [CrossRef]

154. Preedy, M.E.J. Cardiac Cyclic Nucleotide Phosphodiesterases: Roles and Therapeutic Potential in Heart Failure. Cardiovasc. Drugs Ther. 2020, 34, 401-417. [CrossRef]

155. Mika, D.; Bobin, P.; Pomé Rance, M.; Lechê Ne, P.; Westenbroek, R.E.; Catterall, W.A.; Goire Vandecasteele, G.; Rô Me Leroy, J.; Fischmeister, R. Differential regulation of cardiac excitation-contraction coupling by cAMP phosphodiesterase subtypes. Cardiovasc. Res. 2013, 100, 336-346. [CrossRef]

156. Vandecasteele, G.; Verde, I.; Rücker-Martin, C.; Donzeau-Gouge, P.; Fischmeister, R. Cyclic GMP regulation of the L-type $\mathrm{Ca}^{2+}$ channel current in human atrial myocytes. J. Physiol. 2001, 533, 329-340. [CrossRef]

157. Rivet-Bastide, M.; Vandecasteele, G.; Hatem, S.; Verde, I.; Bénardeau, A.; Mercadier, J.-J.; Fischmeister, R. cGMP-stimulated cyclic nucleotide phosphodiesterase regulates the basal calcium current in human atrial myocytes. J. Clin. Investig. 1997, 99, 2710-2718. [CrossRef]

158. Dittrich, M.; Jurevicius, J.; Georget, M.; Rochais, F.; Fleischmann, B.K.; Hescheler, J.; Fischmeister, R. Local response of L-type $\mathrm{Ca}^{2+}$ current to nitric oxide in frog ventricular myocytes. J. Physiol. 2001, 534, 109-121. [CrossRef]

159. Han, X.; Shimoni, Y.; Giles, W.R. A cellular mechanism for nitric oxide-mediated cholinergic control of mammalian heart rate. J. Gen. Physiol. 1995, 106, 45-65. [CrossRef]

160. Bastug-Özel, Z.; Wright, P.T.; Kraft, A.E.; Pavlovic, D.; Howie, J.; Froese, A.; Fuller, W.; Gorelik, J.; Shattock, M.J.; Nikolaev, V.O. Heart failure leads to altered $\beta 2$-adrenoceptor/cyclic adenosine monophosphate dynamics in the sarcolemmal phospholemman/Na,K ATPase microdomain. Cardiovasc. Res. 2019, 115, 546-555. [CrossRef] [PubMed]

161. Dawei, L.; Zhenyu, W.; Valérie, N.; Marta, L.; Delphine, M.; Grégoire, V.; Rodolphe, F.; Catherine, B. PDE2 regulates membrane potential, respiration and permeability transition of rodent subsarcolemmal cardiac mitochondria. Mitochondrion 2019, 47, 64-75. [CrossRef]

162. Acin-Perez, R.; Russwurm, M.; Günnewig, K.; Gertz, M.; Zoidl, G.; Ramos, L.; Buck, J.; Levin, L.R.; Rassow, J.; Manfredi, G.; et al. A Phosphodiesterase 2A Isoform Localized to Mitochondria Regulates Respiration. J. Biol. Chem. 2011, 286, 30423-30432. [CrossRef] [PubMed]

163. Wang, Z.; Liu, D.; Varin, A.; Nicolas, V.; Courilleau, D.; Mateo, P.; Caubere, C.; Rouet, P.; Gomez, A.M.; Vandecasteele, G.; et al. A cardiac mitochondrial cAMP signaling pathway regulates calcium accumulation, permeability transition and cell death. Cell Death Dis. 2016, 7, e2198. [CrossRef] [PubMed]

164. Pozdniakova, S.; Guitart-Mampel, M.; Garrabou, G.; Di Benedetto, G.; Ladilov, Y.; Regitz-Zagrosek, V. $17 \beta$-Estradiol reduces mitochondrial cAMP content and cytochrome oxidase activity in a phosphodiesterase 2-dependent manner. Br. J. Pharmacol. 2018, 175, 3876-3890. [CrossRef] 
165. Gustafsson, Å.B.; Brunton, L.L. Interactions of the Cyclic AMP and Nitric Oxide Pathways in Cardiac Fibroblasts. In Pathophysiology of Cardiovascular Disease: Progress in Experimental Cardiology; Dhalla, N.S., Rupp, H., Angel, A., Pierce, G., Eds.; Springer: Boston, MA, USA, 2004; pp. 109-123.

166. Gustafsson, Å.B.; Brunton, L.L. $\beta$-Adrenergic stimulation of rat cardiac fibroblasts enhances induction of nitric-oxide synthase by interleukin-1 $\beta$ via message stabilization. Mol. Pharmacol. 2000, 58, 1470-1478. [CrossRef]

167. Delaunay, M.; Osman, H.; Kaiser, S.; Diviani, D. The Role of Cyclic AMP Signaling in Cardiac Fibrosis. Cells 2019, 9, 69. [CrossRef]

168. Rowley, J.W.; Oler, A.J.; Tolley, N.D.; Hunter, B.N.; Low, E.N.; Nix, D.A.; Yost, C.C.; Zimmerman, G.A.; Weyrich, A.S. Genome-wide RNA-seq analysis of human and mouse platelet transcriptomes. Blood 2011, 118, e101. [CrossRef]

169. Rondina, M.T.; Weyrich, A.S. Targeting Phosphodiesterases in Anti-platelet Therapy. Handb. Exp. Pharmacol. 2012, 225-238.

170. Xiang, Q.; Pang, X.; Liu, Z.; Yang, G.; Tao, W.; Pei, Q.; Cui, Y. Progress in the development of antiplatelet agents: Focus on the targeted molecular pathway from bench to clinic. Pharmacol. Ther. 2019, 203, 107393. [CrossRef]

171. Dickinson, N.T.; Jang, E.K.; Haslam, R.J. Activation of cGMP-stimulated phosphodiesterase by nitroprusside limits cAMP accumulation in human platelets: Effects on platelet aggregation. Biochem. J. 1997, 323, 371-377. [CrossRef] [PubMed]

172. Favot, L.; Keravis, T.M.; Lugnier, C. VEGF-induced HUVEC migration and proliferation are decreased by PDE2 and PDE4 inhibitors. Thromb. Haemost. 2003, 90, 334-343. [CrossRef] [PubMed]

173. Trevor, A.; Katzung, B.; Masters, S.; Kruidering-Hall, M. Pharmacology Examination E Board Review, 11th ed.; McGraw-Hill Medical: New York, NY, USA, 2010; pp. 121-132.

174. Cuffe, M.S.; Califf, R.M.; Adams, K.F.; Benza, R.; Bourge, R.; Colucci, W.S.; Massie, B.M.; O'Connor, C.M.; Pina, I.; Quigg, R.; et al. Short-term intravenous milrinone for acute exacerbation of chronic heart failure: A randomized controlled trial. J. Am. Med. Assoc. 2002, 287, 1541-1547. [CrossRef] [PubMed]

175. Rita Assenza, M.; Barbagallo, F.; Barrios, F.; Cornacchione, M.; Campolo, F.; Vivarelli, E.; Gianfrilli, D.; Auletta, L.; Soricelli, A.; Isidori, A.M.; et al. Critical role of phosphodiesterase 2A in mouse congenital heart defects. Cardiovasc. Res. 2018, 114, 830-845. [CrossRef]

176. Hua, R.; Adamczyk, A.; Robbins, C.; Ray, G.; Rose, R.A. Distinct Patterns of Constitutive Phosphodiesterase Activity in Mouse Sinoatrial Node and Atrial Myocardium. PLoS ONE 2012, 7, e47652. [CrossRef]

177. Isidori, A.M.; Cornacchione, M.; Barbagallo, F.; Di Grazia, A.; Barrios, F.; Fassina, L.; Monaco, L.; Giannetta, E.; Gianfrilli, D.; Garofalo, S.; et al. Inhibition of type 5 phosphodiesterase counteracts $\beta 2$-adrenergic signalling in beating cardiomyocytes. Cardiovasc. Res. 2015, 106, 408-420. [CrossRef]

178. Yanaka, N.; Kurosawa, Y.; Minami, K.; Kawai, E.; Omori, K. Cgmp-Phosphodiesterase Activity Is Up-regulated in Response to Pressure Overload of Rat Ventricles. Biosci. Biotechnol. Biochem. 2003, 67, 973-979. [CrossRef]

179. Nash, C.A.; Brown, L.M.; Malik, S.; Cheng, X.; Smrcka, A.V. Compartmentalized cyclic nucleotides have opposing effects on regulation of hypertrophic phospholipase $\mathrm{C} \varepsilon$ signaling in cardiac myocytes. J. Mol. Cell. Cardiol. 2018, 121, 51-59. [CrossRef]

180. Wagner, M.; Mehel, H.; Fischmeister, R.; El-Armouche, A. Phosphodiesterase 2: Anti-adrenergic friend or hypertrophic foe in heart disease? Naunyn Schmiedebergs Arch. Pharmacol. 2016, 389, 1139-1141. [CrossRef]

181. Rodríguez-Sinovas, A.; Yaser, A.E.; Ae, A.; Michael, H.; Ae, P.; Garcia-Dorado, D. Reperfusion injury as a therapeutic challenge in patients with acute myocardial infarction. Heart Fail. Rev. 2007, 12, 207-216. [CrossRef]

182. Garcia-Dorado, D.; Ruiz-Meana, M.; Inserte, J.; Rodriguez-Sinovas, A.; Piper, H.M. Calcium-mediated cell death during myocardial reperfusion. Cardiovasc. Res. 2012, 94, 168-180. [CrossRef] [PubMed]

183. Halestrap, A.P.; Richardson, A.P. The mitochondrial permeability transition: A current perspective on its identity and role in ischaemia/reperfusion injury. J. Mol. Cell. Cardiol. 2015, 78, 129-141. [CrossRef] [PubMed]

184. Rinaldi, L.; Pozdniakova, S.; Jayarajan, V.; Troidl, C.; Abdallah, Y.; Aslam, M.; Ladilov, Y. Protective role of soluble adenylyl cyclase against reperfusion-induced injury of cardiac cells. Biochim. Biophys. Acta 2019, 1865, 252-260. [CrossRef] [PubMed]

185. Acin-Perez, R.; Salazar, E.; Kamenetsky, M.; Buck, J.; Levin, L.R.; Manfredi, G. Cyclic AMP Produced inside Mitochondria Regulates Oxidative Phosphorylation. Cell Metab. 2009, 9, 265-276. [CrossRef] [PubMed] 
186. Chen, W.; Spitzl, A.; Mathes, D.; Nikolaev, V.O.; Werner, F.; Weirather, J.; Špiranec, K.; Röck, K.; Fischer, J.W.; Kämmerer, U.; et al. Endothelial Actions of ANP Enhance Myocardial Inflammatory Infiltration in the Early Phase after Acute Infarction. Circ. Res. 2016, 119, 237-248. [CrossRef]

187. Chen, W.; Oberwinkler, H.; Werner, F.; Ganer, B.; Nakagawa, H.; Feil, R.; Hofmann, F.; Schlossmann, J.; Dietrich, A.; Gudermann, T.; et al. Atrial natriuretic peptide-mediated inhibition of microcirculatory endothelial $\mathrm{Ca}^{2+}$ and permeability response to histamine involves cGMP-dependent protein kinase $\mathrm{i}$ and TRPC6 channels. Arterioscler. Thromb. Vasc. Biol. 2013, 33, 2121-2129. [CrossRef]

188. Oka, T.; Akazawa, H.; Naito, A.T.; Komuro, I. Angiogenesis and Cardiac Hypertrophy. Circ. Res. 2014, 114, 565-571. [CrossRef]

189. Nakamura, M.; Sadoshima, J. Mechanisms of physiological and pathological cardiac hypertrophy. Nat. Rev. Cardiol. 2018, 15, 387-407. [CrossRef]

190. Izumiya, Y.; Shiojima, I.; Sato, K.; Sawyer, D.B.; Colucci, W.S.; Walsh, K. Vascular endothelial growth factor blockade promotes the transition from compensatory cardiac hypertrophy to failure in response to pressure overload. Hypertension 2006, 47, 887-893. [CrossRef]

191. Friehs, I.; Margossian, R.E.; Moran, A.M.; Cao-Danh, H.; Moses, M.A.; Del Nido, P.J.; Friehs, I.; Cao-Danh, H.; Del Nido, P.J.; Margossian, R.E.; et al. Vascular endothelial growth factor delays onset of failure in pressure-overload hyper-trophy through matrix metalloproteinase activation and angiogenesis. Basic Res. Cardiol. 2006, 101, 204-213. [CrossRef]

192. Sahara, M.; Sata, M.; Morita, T.; Nakajima, T.; Hirata, Y.; Nagai, R. A phosphodiesterase-5 inhibitor vardenafil enhances angiogenesis through a protein kinase g-dependent hypoxia-inducible factor-1/vascular endothelial growth factor pathway. Arterioscler. Thromb. Vasc. Biol. 2010, 30, 1315-1324. [CrossRef] [PubMed]

193. Diebold, I.; Djordjevic, T.; Petry, A.; Hatzelmann, A.; Tenor, H.; Hess, J.; Görlach, A. Phosphodiesterase 2 mediates redox-sensitive endothelial cell proliferation and angiogenesis by thrombin via rac1 and NADPH oxidase 2. Circ. Res. 2009, 104, 1169-1177. [CrossRef] [PubMed]

194. Neviere, R.; Delguste, F.; Durand, A.; Inamo, J.; Boulanger, E.; Preau, S. Abnormal Mitochondrial cAMP/PKA Signaling Is Involved in Sepsis-Induced Mitochondrial and Myocardial Dysfunction. Int. J. Mol. Sci. 2016, 17, 2075. [CrossRef] [PubMed]

195. Farber, H.W.; Loscalzo, J. Pulmonary Arterial Hypertension. N. Engl. J. Med. 2004, 351, 1655-1665. [CrossRef] [PubMed]

196. Bubb, K.J.; Trinder, S.L.; Baliga, R.S.; Patel, J.; Clapp, L.H.; MacAllister, R.J.; Hobbs, A.J. Inhibition of phosphodiesterase 2 augments cGMP and cAMP signaling to ameliorate pulmonary hypertension. Circulation 2014, 130, 496-507. [CrossRef] [PubMed]

197. McLaughlin, V.V.; McGoon, M.D. Pulmonary arterial hypertension. Circulation 2006, 114, 1417-1431. [CrossRef] [PubMed]

198. Ishak Gabra, N.B.; Mahmoud, O.; Ishikawa, O.; Shah, V.; Altshul, E.; Oron, M.; Mina, B. Pulmonary Arterial Hypertension and Therapeutic Interventions. Int. J. Angiol. 2019, 28, 80-82. [CrossRef]

199. Thenappan, T.; Ormiston, M.L.; Ryan, J.J.; Archer, S.L. Pulmonary arterial hypertension: Pathogenesis and clinical management. BMJ 2018, 360. [CrossRef]

200. Jing, Z.C.; Yu, Z.X.; Shen, J.Y.; Wu, B.X.; Xu, K.F.; Zhu, X.Y.; Pan, L.; Zhang, Z.L.; Liu, X.Q.; Zhang, Y.S.; et al. Vardenafil in pulmonary arterial hypertension: A randomized, double-blind, placebo-controlled study. Am. J. Respir. Crit. Care Med. 2011, 183, 1723-1729. [CrossRef]

201. Rubin, L.J.; Badesch, D.B.; Fleming, T.R.; Galiè, N.; Simonneau, G.; Ghofrani, H.A.; Oakes, M.; Layton, G.; Serdarevic-Pehar, M.; McLaughlin, V.V.; et al. Long-term treatment with sildenafil citrate in pulmonary arterial hypertension: The SUPER-2 study. Chest 2011, 140, 1274-1283. [CrossRef]

202. Zhang, C.; Lueptow, L.M.; Zhang, H.T.; O’Donnell, J.M.; Xu, Y. The role of phosphodiesterase-2 in psychiatric and neurodegenerative disorders. Adv. Neurobiol. 2017, 17, 307-347. [PubMed]

203. Domek-Łopacińska, K.; Strosznajder, J.B. The effect of selective inhibition of cyclic GMP hydrolyzing phosphodiesterases 2 and 5 on learning and memory processes and nitric oxide synthase activity in brain during aging. Brain Res. 2008, 1216, 68-77. [CrossRef] [PubMed]

204. Sierksma, A.S.R.; Rutten, K.; Sydlik, S.; Rostamian, S.; Steinbusch, H.W.M.; Van Den Hove, D.L.A.; Prickaerts, J. Chronic phosphodiesterase type 2 inhibition improves memory in the APPswe/PS1dE9 mouse model of Alzheimer's disease. Neuropharmacology 2013, 64, 124-136. [CrossRef] [PubMed] 
205. Helal, C.J.; Arnold, E.; Boyden, T.; Chang, C.; Chappie, T.A.; Fisher, E.; Hajos, M.; Harms, J.F.; Hoffman, W.E.; Humphrey, J.M.; et al. Identification of a Potent, Highly Selective, and Brain Penetrant Phosphodiesterase 2A Inhibitor Clinical Candidate. J. Med. Chem. 2018, 61, 1001-1018. [CrossRef]

206. Mikami, S.; Nakamura, S.; Ashizawa, T.; Nomura, I.; Kawasaki, M.; Sasaki, S.; Oki, H.; Kokubo, H.; Hoffman, I.D.; Zou, H.; et al. Discovery of Clinical Candidate N-((1S)-1-(3-Fluoro-4-(trifluoromethoxy)phenyl)-2-methoxyethyl)-7-methoxy2-oxo-2,3-dihydropyrido[2,3-b]pyrazine-4(1H)-carboxamide (TAK-915): A Highly Potent, Selective, and Brain-Penetrating Phosphodiesterase 2A Inhibitor for the Treatment of Cognitive Disorders. J. Med. Chem. 2017, 60, 7677-7702. [CrossRef]

207. Mikami, S.; Sasaki, S.; Asano, Y.; Ujikawa, O.; Fukumoto, S.; Nakashima, K.; Oki, H.; Kamiguchi, N.; Imada, H.; Iwashita, H.; et al. Discovery of an Orally Bioavailable, Brain-Penetrating, in Vivo Active Phosphodiesterase 2A Inhibitor Lead Series for the Treatment of Cognitive Disorders. J. Med. Chem. 2017, 60, 7658-7676. [CrossRef]

208. Griffiths, G.J. Exisulind Cell Pathways. Curr. Opin. Investig. Drugs 2000, 1, 386-391.

(C) 2020 by the authors. Licensee MDPI, Basel, Switzerland. This article is an open access article distributed under the terms and conditions of the Creative Commons Attribution (CC BY) license (http://creativecommons.org/licenses/by/4.0/). 